\title{
CARTOGRAFANDO O RIO DE JANEIRO E SEUS MUSEUS: NOTAS SOBRE UMA "ETNOGRAFIA AUDIOVISUAL DE PERCURSOS"
}

\begin{abstract}
Resumo:
O presente artigo apresenta alguns resultados do projeto "Museus do Rio" voltado para o conhecimento e difusão dos museus localizados no Estado do Rio de Janeiro. Especial atenção é conferida à metodologia utilizada que denominamos de "etnografia audiovisual dos percursos", bem como à participação no projeto de alunos da graduação em Museologia e da pós-graduação em Memória Social da UNIRIO no Rio de Janeiro. Por meio da pesquisa de campo e, particularmente, do uso do audiovisual, os alunos foram levados a exercitar a perspectiva etnográfica e conhecer mais de perto os processos de construção de memória social que os museus engendram, especialmente a relação da memória coletiva com a dinâmica social (Halbwachs, 1990; Huyssen, 2000). A metodologia da "Etnografia audiovisual dos percursos" fez uso de recursos audiovisuais, digitais e fotográficos, gerando produtos que posteriormente foram disponibilizados no portal www.museusdorio. com.br. Pretendemos, com base nesta experiência, introduzir novas ferramentas capazes de dinamizar a relação entre ensino e pesquisa numa relação de inter-conectividade.
\end{abstract}

\author{
Regina Abreu'
}

\footnotetext{
I Doutora em Antropologia Social pela Universidade Federal do Rio de Janeiro (Museu Nacional), Especialização em "Recherches en Sciences Sociales" (EHESS), Professora Associada da Universidade Federal do Estado do Rio de Janeiro (UNIRIO), Bolsista de Produtividade do CNPq 2; Integrante do Corpo Docente do Programa de Pós-Graduação em Memória Social/UNIRIO (certificado pela CAPES/área Interdisciplinar), Líder do Grupo de Pesquisa CNPq "Memória, Cultura e Patrimônio", Coordenadora do Projeto de Pesquisa "A Patrimonialização das Diferenças" (apoio CNPq), Coordenadora do Portal "Museus do Rio" (apoio Faperj). Atuou como pesquisadora visitante do Institut de Recherche Interdisciplinaire sur les enjeux sociaux-IRIS. Tem experiência na área de Antropologia Social nas interfaces com a Memória Social, o Patrimônio Cultural, os Museus, o Áudio-Visual e o Estudo de Trajetórias.
} 


\section{I.Apresentação:}

A Antropologia Cultural é uma área de conhecimento consolidada na grade curricular dos Cursos de Museologia, iniciando o futuro museólogo na percepção do pensamento antropológico e de sua contribuição para a área interdisciplinar dos museus, da memória e da patrimonialização. Do ponto de vista teórico, o trabalho de docência tem se ancorado no importante avanço dos estudos sobre a cultura material - objetos, coleções e patrimônios -. São cotejados antropólogos clássicos como Malinowski (Kula Melanésio), Marcel Mauss (Ensaio sobre o dom), Edmund Leach (Sobre o tempo), Claude Lévi-Strauss (etnografia e museus) e também autores contemporâneos internacionais como Arjun Appadurai (A vida social das coisas), Stocking W., Jr. (Objects and Others. Essays on Museums and Material Culture); James Clifford (Colecionando Arte e Cultura); Richard Handler (On Having a Culture: Nationalism and the Preservation of Quebec's Patrimoine); K. Pomian (Coleção) e nacionais como José Reginaldo Santos Gonçalves (A retórica da Perda); Dominique T. Gallois (Patrimônio Cultural Imaterial e Povos Indígenas); Regina Abreu e Mario Chagas (Memória e Patrimônio: Ensaios Contemporâneos); Myrian Sepulveda dos Santos (O discurso do passado nos museus históricos). Estas reflexões estimulam o aluno a pensar antropologicamente o campo dos museus, dos patrimônios e das coleções. Observa-se também um progressivo incremento de produção de teses e dissertações nos cursos de Pós-Graduação em Antropologia, Museologia e áreas interdisciplinares, como o Programa de Pós-Graduação em Memória Social, focalizando a criação de museus, a formação de coleções, a patrimonialização de bens imóveis e bens móveis (IPHAN-Decreto Lei 25/I937) e a patrimonialização das culturas (Programa Nacional de Patrimônio Imaterial).

Trabalhando no curso de graduação em Museologia e no Programa de Pós-Graduação em Memória Social da UNIRIO e buscando uma articulação entre ensino e pesquisa na interface entre estas áreas, formulamos o projeto "Museus do Rio". Neste, os museus do estado do Rio de Janeiro são tomados como locus de pesquisas de campo, onde os alunos são convidados a exercitar a perspectiva etnográfica e a conhecer mais de perto os processos de construção de memória social que os museus engendram. $O$ uso do audiovisual é constitutivo da proposta e se consubstancia na metodologia da "etnografia audiovisual dos percursos". O objetivo consiste em documentar e pesquisar museus do Estado do Rio de Janeiro, seus agentes, suas narrativas relacionando-os com a história e a memória locais e regionais. Com base na divisão regional do Estado, realizamos 8 roteiros de pesquisas incluindo as regiões Norte e Noroeste Fluminense; Centro Sul Fluminense; Metropolitana; Costa Verde; Baixadas Litorâneas; Serrana; Médio Paraíba. Estas pesquisas resultaram na realização de um portal www.museusdorio.com.br ; nove filmes etnográficos focalizando os percursos visitados ("etnografia audiovisual dos percursos"); um seminário também realizado com apoio da Faperj (Encontro dos Museus do Rio/ 2010). Com base neste material foram realizadas teses, dissertações e monografias sobre os "Museus do Rio" produzindo um conhecimento novo sobre processos de patrimonialização e de construção da memória em contextos onde a pesquisa sobre o tema era pequena ou inexistente. $O$ apoio da Faperj ao projeto, através do Edital Pensa Rio 2007, possibilitou também que constituíssemos o Laboratório de Memória e Imagem do Programa de Pós-Graduação em Memória Social com 
a adequação de um espaço físico e a aquisição de equipamentos de produção e edição de imagem audio-visual, fotográfica e digital. Este Laboratório tornou-se um espaço multi-usuário congregando docentes, discentes e também técnicos da área do audiovisual e das novas tecnologias digitais, alguns dos quais foram contemplados com bolsa de Treinamento e Capacitação Técnica da Faperj. O portal "museusdorio" e as pesquisas e filmes realizados no Laboratório de Memória e Imagem constituem hoje referência na área da Antropologia Cultural, tendo sido apresentados no Brasil e no exterior em congressos e seminários, inclusive no Musée du Quai Branly, em Paris; na Universidade de Évora; no Centro de Estudos Sociais da Universidade de Coimbra; no Centre de Communication et Culture da Université d'Avignon; e no próprio PPGMS/UNIRIO durante - I Seminário Internacional em Memória Social ocorrido em 2012 e na Jornada de Memória e Patrimônio em 2014.

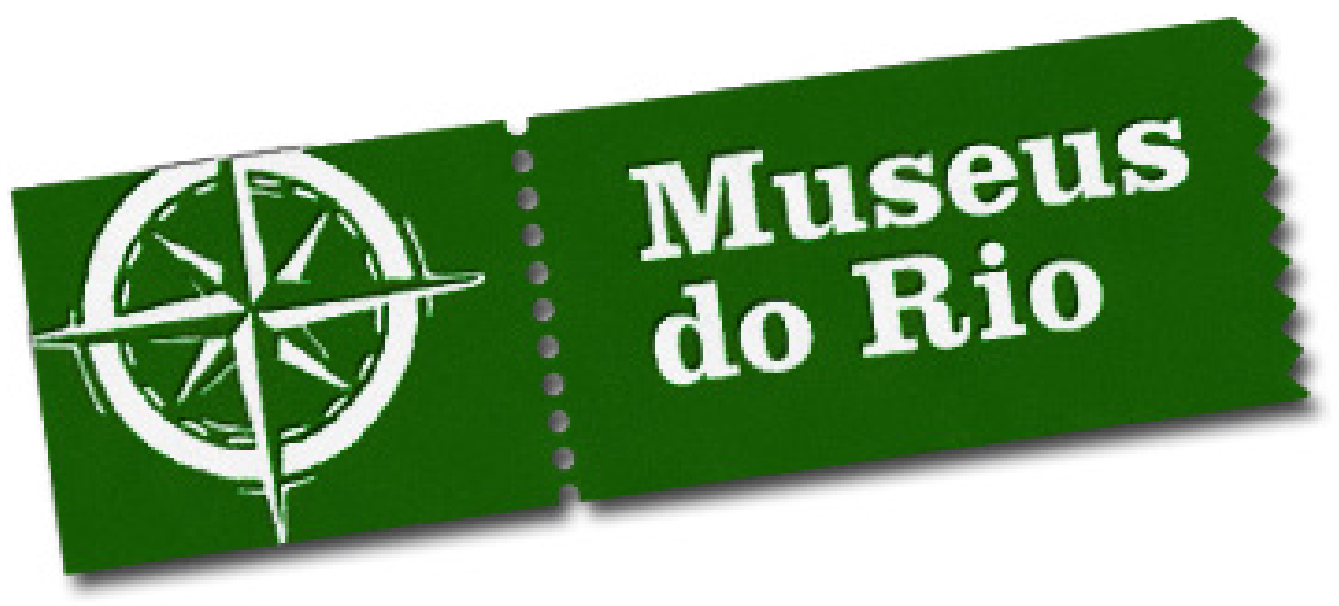

\section{Etnografia Audiovisual dos percursos: notas sobre a metodologia de pesquisa}

A inspiração para a metodologia de "etnografia audiovisual dos percursos" veio da leitura de narrativas sobre a experiência do viajante que percorre uma região, buscando exercitar um olhar que estranha, que inquire, que indaga, que procura novos ângulos, novas perspectivas, novas faces de paisagens já vistas e consagradas.

Queremos encontrar o Rio de Janeiro para além das paisagens já monumentalizadas, do outro lado do pão de açúcar, do Corcovado, das belas praias, da zona sul, para além da própria cidade do Rio de Janeiro.Ao focalizar o estado do Rio de Janeiro falamos de uma duplicidade de sentidos - cidade e estado O Rio de Janeiro é a cidade, capital de um também estado do Rio de Janeiro. Esta superposição de nomes não é casual. Ela implica histórias complexas, conseqüências de forças políticas contrárias, tensões, disputas. Habitar o Rio de Janeiro expressa construções muito variadas e polissêmicas sinalizando cidadãos de uma cidade e/ou de um estado. Identidades e diferenças que falam da proximidade com o mar, com o litoral, com as conexões internacionais e que também falam do sertão, do interior, de conexões com outros estados, Minas Gerais, Espírito Santo, São Paulo. Rio de Janeiro é sinônimo de foras e dentros, cariocas e fluminenses. Cartografar o Rio de Janeiro, palmilhá-lo, percorrê-lo significa lançar-se numa aventura de trilhas, histórias, imaginários raramente coincidentes. $A$ 
polifonia da região está em cada trecho. Região de ocupação muito antiga, onde praticamente toda a história do país é revista e recontada por muitas gerações de grupos sociais diferentes e contraditórios. Desde o início, sabíamos que não teríamos registros únicos. Pelo contrário, as pistas nos sinalizavam que a tendência seria caminhar por camadas de sentidos que conviviam coetâneas, embora muitos séculos as separassem. Numa mesma área, ouvíamos falar de registros de quilombolas, bandeirantes, povos indígenas, fazendeiros, empresários, aventureiros, viajantes, indivíduos vindos de diferentes procedências: portugueses, franceses, tamoios, sambaquieiros, turcos, italianos, africanos, tupiniquins... Como cartografar uma região tão ampla e tão repleta de imaginários? Como trabalhar com a riqueza da diversidade de museus numa região que já foi sede do Governo português, da Colônia, do Império, da República? Uma região onde se fizeram as bases da economia do país, as primeiras elites econômicas e políticas, as muitas relações de trabalho - escravidão, trabalho assalariado, serviços terceirizados-? Como não perceber de imediato que muitos dos quase trezentos museus do Rio de Janeiro contam também histórias do Rio de Janeiro, vestígios que são de antigas construções, fazendas, palácios, casas de remanescentes de quilombos, ruínas de antigas estações ferroviárias. Para a construção da nossa metodologia de pesquisa esta foi pois nossa primeira assertiva: partimos da noção de que os museus do Rio de Janeiro constituíam signos de múltiplas narrativas sobre si mesmos e sobre o espaço onde se inseriam. Por outro lado, estas narrativas aparentavam, desde o contato com o tema, um aspecto extremamente fragmentário. Eram como ruínas no sentido atribuído por Walter Benjamin, sinais de mundos já desaparecidos. Todas as tentativas de estabelecer grandes narrativas que os interligassem em algum sistema comum parecia já ter fracassado.'

Focalizar os museus no contexto das paisagens como ruínas expressivas que sinalizam para camadas variadas de significados nos colocava numa perspectiva bem diferente de uma análise dos museus como instituições. Deste ponto de vista, afastamo-nos de quaisquer sistemas classificatórios e da atribuição de qualidades tipológicas às instituições. Partir destes sistemas classificatórios, muito em voga na teoria museológica contemporânea, e muito úteis para pesquisas que focalizam os museus como instituições, não foi nossa opção. $\bigcirc$ objetivo principal desta pesquisa não consistiu em refletir sobre os museus a partir de pressupostos como suas funções sociais, suas características internas (prédio ou espaço ressignificado; coleção e tipo de acervo; vocação; existência ou não de plano museológico). Nesta pesquisa, de caráter antropológico, não priorizamos como ponto de partida as normativas do campo museal que definem a categoria museu e suas variantes: museu tradicional; eco-museu; museu social; entre outras. Nosso interesse foi o de observar os museus como personagens, ou como "aldeias" espalhadas por diversos territórios. Como personagens ou "aldeias" queríamos deixar que suas histórias de vida falassem por si só, com o mínimo de interferência de nossa parte.

Partindo de uma concepção mais alargada que o conceito de ruína formulado por Benjamin possibilita, entendemos que muitos destes lugares chama-

I Em artigo anterior, desenvolvi uma reflexão sobre o conceito de ruínas de Walter Benjamin.Ver:ABREU, Regina . Colecionando museus como ruínas: percursos e experiências de memórias no contexto de ações patrimoniais. Ilha. Revista de Antropologia (Florianópolis), v. I, p. 17-37, 2012. In: <www.reginaabreu.com> 
dos museus trazem em si marcas de ruínas, enquanto elementos e vestígios de múltiplas temporalidades que entram em choque com a temporalidade dominante do mundo pós-urbano, industrial e, mais recentemente, do mundo pós-revolução do silício com a hegemonia das novas tecnologias digitais. Desse modo, a metodologia da "etnografia audiovisual dos percursos" envolvia antes de mais nada a busca de alteridades no espaço e no tempo. Com relação às definições sobre o que é ou não um museu, preferimos partir de duas assertivas: uma, o Cadastro Nacional de Museus ${ }^{2}$, metodologia implementada pelo Instituto Brasileiro de Museus que conta com uma forte perspectiva antropológica, mapeando os museus em contexto nacional, a partir de uma proposição social. Entende-se assim que aqueles lugares considerados museus pelos grupos que os implementam devem ser mapeados e levados em consideração, ainda que muitos deles fujam aos critérios normativos museológicos. $O$ que nos interessou foi perceber da parte da sociedade uma "vontade museal", como já assinalou o museólogo Mario Chagas, que derivou este conceito de uma pesquisa sobre a "imaginação museal" nos museus brasileiros. De acordo com Chagas, a "imaginação museal" expressa uma articulação num determinado espaço de uma narrativa poética das coisas a partir do protagonismo de um ou mais sujeitos. Esta articulação advém de uma "vontade museal". Tomar como objeto de pesquisa compreender e interpretar os significados desta "vontade museal" pode, no entender de Chagas, nos auxiliar na compreensão das relações sociais que lhes são subjacentes. ${ }^{3}$

Desse modo, o Cadastro Nacional de Museus, coordenado pela museóloga Rose Miranda no contexto do setor do IBRAM coordenado então pelo museólogo Mario Chagas, nos serviu desde o início como referência dos museus que poderiam ser visitados e pesquisados, sem levar em conta normativas do campo museal que, neste caso limitariam nosso universo de pesquisa. Entendíamos que trabalhando com um conceito mais alargado e fundamentalmente antropológico de museu (museu como alteridade, ou seja, aquilo que as pessoas nomeiam como tal), seria possível perceber os lugares considerados pela sociedade como referências de memória coletiva. Como a pesquisa tinha como objetivo focalizar diferentes memórias sociais e coletivas no Estado do Rio de Janeiro, seria de pouca valia considerar os museus apenas como instituições, bem como partir de um sistema classificatório já previamente delimitado.

A outra assertiva da qual partimos foi a noção de "cartografia". Como assinalou, Danichi Hausen Mizoguchi, cartografia na terminologia utilizada pelos geógrafos, "é o desenho que acompanha e se faz simultaneamente aos movimentos da paisagem. Produção de conhecimento que se dá numa zona de dupla captura entre singularidades: um corpo curioso e um mundo que o atiça. Sendo fabricada em tal zona, a cartografia presta-se a escapar dos grudentos decalques pré-fabricados sempre prontos a serem aderidos a toda e qualquer superfície, diminuindo a miríade dos registros a um punhado de expressões prêt-à-porter." 4

A utilização da cartografia como método de aproximação com uma

2 Ver o portal do Sistema Brasileiro de Museus e o Portal <www.museusdorio.com> que contém a publicação completa do Cadastro Nacional de Museus do IBRAM.

3 Ver: CHAGAS, Mario. A imaginação museal:museu, memória e poder em Gustavo Barroso, Gilberto Freyre e Darcy Ribeiro. Rio de Janeiro: Ibram/Garamond, 2009.

4 Mizoguchi, Danichi Hausen, Segmentaricidades: passagens do leme ao pontal, SP, Ed. Pleiade, 2009, pág. 84 
quantidade e uma diversidade de museus nos permitia uma aproximação também com outra noção, a de território. Para além das instituições, buscávamos prédios, casas, lugares com íntima conexão com os territórios que habitavam, capazes de expressar histórias locais, de falar para além do escopo institucional. Viver a experiência de cartografar, ir ao encontro de vestígios de mundos desaparecidos possibilitariam a nosso ver encontros inesperados, interlocuções e afetações impensadas.

A própria idéia do percurso trazia para nós este espírito de aventura e de continuidade, onde não esperávamos esgotar a pesquisa num conjunto pré-determinado de museus, mas, pelo contrário, abrir portas e forçar passagens para outras pesquisas, trocas e interlocuções. $O$ pesquisador, a nosso ver, dispõe deste poder de situar-se num ponto de vista de liminaridade, de fora e de dentro, de passagem como o viajante ou o aventureiro.Aproveitar-se e levar às últimas consequências desta posição era a aposta para que pudéssemos desvendar outros mundos focando nas memórias e nas histórias construídas socialmente.

A ferramenta da cartografia permitia também constituir um precioso material para a escrita posterior, atualizando e verbalizando aquilo que antes existia como virtualidade e potencialidade. A cartografia dos museus a partir de percursos pré-definidos forneceria material para narrativas antes impensadas sobre estes territórios e suas memórias.A aposta era a de construir uma escrita possível dos museus e das memórias sociais locais, entendendo como chama atenção Danichi Hausen Mizouguchi, a partir de uma formulação de Deleuze e Guattari, que "escrever nada tem a ver com significar, mas com agrimensar". ${ }^{5}$

Outro conceito-chave utilizado foi o de "etnografia" e, mais especialmente, o de "etnografia audiovisual". Como assinalou Cornelia Eckert, "a prática etnográfica é o ofício do(a) antropólogo(a) social.Trata-se de uma metodologia que se desenvolveu vinculada aos quadros teóricos e conceituais desenvolvidos pelos intelectuais da Antropologia em diferentes ambientes universitários e institucionais e em diversos processos históricos. Ela envolve, de modo singular, as ações de observar, de escutar e de registrar na forma escrita como técnicas de pesquisa operacionalizadas: observações, entrevistas e descrições dos processos de interação com indivíduos e grupos em seus dinamismos macro e micro estruturais. Neste princípio, a grafia das diversidades socioculturais ultrapassa os projetos reacionários de perspectivas realistas e chega à contemporaneidade com disposições dialógicas de enfrentamento das determinações ideológicas e coercitivas e alcança qualidades de convivência social e responsabilidade política de complexidade planetária."6

Especificamente, a "etnografia audiovisual" surge no século $X X$ como uma ferramenta sintonizada com "as invenções de instrumentos de registros fotográficos, sonoros e, em sequencia, dos registros fílmicos". ${ }^{7}$ Já os primeiros antropólogos modernos utilizavam câmeras fotográficas, filmadoras e gravadores para reproduzirem as entrevistas e as observações feitas em campo e poderem refletir sobre elas e tecerem análises posteriores. Cada vez mais, estas técni-

5 Mizouguchi, op. cit., pág. 85 (Ver também Deleuze, Gilles e Guattari, Felix, Introdução: rizoma. Em Mil Platôs: capitalismo e esquizofrenia.Volume I. Rio de Janeiro: Editora 34, 1995).

6 Eckert, Cornelia, "Apresentação", In: Revista lluminuras, v. I3, n. 32 (20।3).

7 Eckert, op. cit. 
cas foram se aperfeiçoando e sendo incorporadas ao ofício do antropólogo. Concomitantemente, traziam também debates, dilemas, reflexões, sobretudo, relacionados à ética, à linguagem e ao tema dos direitos das populações com relação à difusão de suas imagens e falas. Vimos nascer uma área especializada nesta reflexão -a Antropologia Visual-, com uma gama intensa de seminários, colóquios, artigos, cursos e com adeptos de forma crescente. Como chama a atenção ainda Cornelia Eckert, "um aprimoramento técnico e dramático das aprendizagens etnográficas nos legou hoje um rico patrimônio de produção em imagens visuais e sonoras."8

O uso do audiovisual na pesquisa de campo permite desvendar detalhes imperceptíveis durante o processo da pesquisa, o enriquecimento das minúcias na perspectiva do observador é notável. Como assinalou Cornelia Eckert e Ana Luisa Carvalho da Rocha, a ferramenta do audiovisual é herdeira direta do "ideário da Modernidade que conforma um olhar humano sobre o mundo cuja finalidade é, precisamente, observar e dissecar a realidade para melhor descrevê-la e dominá-la."9

Por outro lado, o uso do audiovisual é extremamente performático e, em muitos casos, aproxima e confere dignidade ao interlocutor. A perspectiva de falar diante de uma câmera confere uma solenidade interessante à entrevista, afastando o pesquisador da banalidade, tirando da rotina os entrevistados, permitindo um outro olhar para aquilo que é da ordem do cotidiano, do trivial, do dia a dia. Eckert e Rocha chamam a atenção para o lugar que o documental e as tecnologias audiovisuais desempenham como "formas de pensar as inflexões temporais características do mundo urbano contemporâneo." Indo mais longe, poderíamos atribuir ao uso das ferramentas audiovisuais uma forma mesma não apenas de registrar, mas de observar e, sobretudo, de refletir. $O$ pesquisador com familiaridade com o uso do audiovisual não mais utiliza a câmera apenas como instrumento que alarga suas potencialidades de ver e ouvir. Trata-se de pensar com o audiovisual. Este axioma de levar uma câmera de vídeo para o campo com o intuito de manejar uma ferramenta que mais do que registrar e documentar faz disparar o pensamento não se trata de uma via de mão única. Não apenas nós os pesquisadores-observadores somos levados a pensar com a câmera, mas também nossos interlocutores. A câmera em cena cria um momento ritual e solene, extraordinário, fora do tempo, que estimula o interlocutor - no nosso caso agentes de memória, diretores de museus, pesquisadores, memorialistas, guias de museus - a uma auto-reflexão. É o momento de parar o trabalho realizado sistematica e cotidianamente e refletir sobre o que se faz, sobre o que se tem feito, sobre o que se fez e o que se pretende fazer. É o momento de refletir sobre o papel do museu, da memória e do patrimônio na comunidade em que se vive, na região e, mais além, no mundo do qual se faz parte. Ao inquirirmos os agentes de memória que trabalham com e pela memória social, damos passagem a que estes agentes se transformem em narradores de si próprios, de suas trajetórias, de suas ações e atitudes para e pela memória social.

$\mathrm{Na}$ sequência das entrevistas, a aposta é que estas narrativas forneçam a base para um texto a partir da transcrição. Este é um capítulo a parte no ofício

8 Eckert, op. cit.

9 Rocha, Ana Luiza Carvalho e Eckert, Cornelia "Imagem recolocada: pensar a imagem como instrumento de pesquisa e análise do pensamento coletivo". In: Revista lluminuras v. 2, n.3; Publicação Eletrônica do Banco de Imagens e Efeitos Visuais - NUPECS/LAS/PPGAS/IFCH e ILEA/UFRGS, 200 I 
do etnógrafo. Como transcrever um texto de narrativa oral, uma entrevista? Ou seja, como transformar uma fala em um texto escrito quando sabemos que falas e textos escritos se inscrevem em contextos muito diferenciados de registros da língua. Muitos tem sido os autores que se dedicam a refletir sobre as agruras, as vantagens e os limites desta transposição. Como transcrever sem trair o pensamento do nosso interlocutor? Como inscrever num texto escrito as figuras de linguagem, as interjeições, as hesitações, os silêncios, as dúvidas, as emoções, enfim, todo um universo de expressões que existe apenas numa narrativa oral? ${ }^{10}$

Além disso, a filmagem produz sempre uma narrativa visual que pode e deve ser contemplada na transcrição das entrevistas. Um olhar, um muxoxo, um gesto, uma piscadela para usar a imagem de Clifford Geertz estão plenas de significados. " Perceber o filme enquanto narrativa visual auxilia muito no trabalho de transcrição das entrevistas. Outra ferramenta muito útil é levar um caderno de campo e anotar impressões, detalhes, sentimentos, questões percebidas durante a pesquisa. É fundamental anotar os nomes dos entrevistados, o local e a data da entrevista. Verena Alberti chama a atenção para o fato de que "A Associação dos Arquivistas Norte-americanos estabeleceu, em um guia de 1995, que as seguintes informações são fundamentais na catalogação de entrevistas de história oral: nome do entrevistado, data, quantidade (de fitas, por exemplo) ou duração, nome do entrevistador, resumo do conteúdo, da natureza e do escopo da entrevista, restrições ao acesso (se houver) e nome do projeto ou coleção (se houver). Outras informações que podem ser acrescentadas às primeiras são: formato físico (gravação sonora, gravação em vídeo, transcrição), informações biográficas do entrevistado, nomes de pessoas presentes, financiadores, circunstâncias da entrevista, sumário, doadores (se houver), restrições de uso e reprodução, materiais suplementares e registro de que a entrevista foi revista pelo entrevistado (se for o caso)." ${ }^{22}$ Quando pensamos em realizar nossas entrevistas, estávamos atentos para o fato de que todo o material gerado poderia ser arquivado no Laboratório de Memória e Imagem do PPGMS-UNIRIO e, que, portanto, deveríamos levar em consideração alguns destes aspectos necessários à inteligibilidade do material produzido tanto para a análise posterior da pesquisa, quanto para usos futuros não previamente definidos. Portanto, elencamos algumas informações básicas necessárias para a pesquisa de campo: anotar os nomes das localidades, os endereços, os nomes das pessoas que nos atendiam, as circunstâncias em que ocorreriam as pesquisas, os nomes das pessoas da equipe durante as viagens e estimulávamos os assistentes de pesquisa a fazerem suas próprias anotações. Tínhamos clareza de que informações deste tipo são

10 Recomendo aos que tem interesse neste tema que recorram a uma literatura especializada.Ver:Alberti, Verena. Tratamento das Entrevistas de História Oral no CPDOC, in: Centro de Pesquisa e Documentação de História Contemporânea do Brasil -CPDOC / FGV -www.cpdoc.fgv.brl < http://cpdoc.fgv.br/producao_intelectual/arq/I505.pdf> acessado em: 9/2/20I5; Ribeiro, José da Silva. Antropologia Visual, Práticas Antigas e Novas Perspectivas de Investigação, Rev.Antropologia, vol 48, n. 2, SP, Jul/Dez 2005< http://www. scielo.br/scielo.php?pid=s0034770| 2005000200007\&script=sci_arttext $>$ acessado em: 9/2/20 I5; Devos, Rafael. "Quando a câmera vira "personagem": ponto de vista em movimento na busca de imagens do outro em documentários etnográficos", in: Revista lluminuras, vol. 2, n. 3, UFRGS, 200 I <http://seer.ufrgs.br/index. php/iluminuras/article/view/9117>.

I I Geertz, Clifford.A Interpretação das Culturas, RJ, Zahar Editores, 1978.

12 Alberti,Verena, Tratamento das Entrevistas de História Oral no CPDOC, in: Centro de Pesquisa e Documentação de História Contemporânea do Brasil -CPDOC / FGV -www.cpdoc.fgv.brl < http://cpdoc. fgv.br/producao_intelectual/arq/I505.pdf> acessado em: 9/2/20I5 
fundamentais numa pesquisa de campo. Realizar uma documentação precisa dos passos da pesquisa e, sobretudo, anotar as referências dos entrevistados são cuidados imprescindíveis neste tipo de trabalho. $E$ tudo isto facilita o momento da transcrição e possibilita a criação de um documento de trabalho para posterior interpretação.

Mas, se estamos falando da metodologia da pesquisa, é importante chamar a atenção para os diversos documentos necessários para a autorização da pesquisa. No nosso caso, trabalhamos com museus e pessoas. Os museus são "pessoas jurídicas" e, neste caso, precisamos solicitar autorização para a pesquisa nestes espaços. $O$ mesmo se coloca para as "pessoas físicas", nossos entrevistados. Hoje, a pesquisa vem sendo regida por normas éticas que visam proteger os direitos de pessoas físicas e jurídicas. Para assegurar a lisura dos objetivos do nosso trabalho enquanto pesquisadores e produtores de conhecimento, é importante que fiquem claras as relações de ambas as partes. No nosso caso, como tínhamos intenção de criar um portal com os resultados da pesquisa difundindo os museus do estado do Rio de Janeiro, além de produzir artigos, livros e difundir o material filmado em filmes para a televisão, deixamos tudo isso muito claro nos documentos que levamos conosco para o campo. Neste caso, ficava definido também que não faríamos uso comercial do material pesquisado e filmado, mas sim um uso cultural e acadêmico, sempre citando as fontes utilizadas.

\section{A Pesquisa de Campo: a escolha dos museus e a construção dos percursos}

Partindo das oito regiões econômicas do Estado do Rio de Janeiro, elaboramos roteiros de visita aos museus procurando observar as conexões e interligações entre os museus e os municípios onde estão situados.A prioridade consistiu em focalizar a relação dos museus com a vida social: os diferentes significados destas instituições para os agentes sociais. A cultura, a memória e os museus de cada região foram previamente pesquisados pela equipe do projeto. Foram também convidados professores e pesquisadores para sugerir percursos e roteiros específicos de visitação para sublinhar as conexões e relações dos museus com o entorno, fosse do ponto de vista histórico, fosse do ponto de vista da memória social dos moradores, fosse do ponto de vista ambiental e artístico, ficando a critério dos convidados sugerir e guiar a equipe no roteiro proposto. O ponto de vista do "narrador" foi sempre sublinhado. Não tínhamos a pretensão de construir roteiros de visita visando englobar "todos" os museus existentes nas regiões pesquisadas. Tratava-se sim de uma proposta conceitual de percurso e visitação cujos nexos e sentidos fossem evidenciados pelos narradores no encontro com a paisagem, a história, a memória, a cultura, os museus.

Assumimos portanto o ponto de vista benjaminiano (Walter Benjamin) onde os nexos e as conexões de memória fossem se explicitando a partir das viagens entre vestígios, fragmentos e ruínas cujos sentidos não eram aparentes. Queríamos insistir na idéia de que os narradores fariam falar os objetos (leia-se museus, ruínas, fragmentos de memória, acervos) ao instigá-los, inquiri-los, dialogar com eles. Procuramos nestas viagens encontrar interlocutores privilegiados (historiadores locais, cronistas, escritores, artistas) que imprimissem um olhar 
singular para os museus, a cultura e a memória de cada roteiro de visitação.

Todo o material foi documentado em vídeo e fotografia visando subsidiar três produtos: um livro, filmes de 12 minutos para cada roteiro, um site. A concepção conceitual do livro, a direção dos filmes e a concepção do site ficaram a cargo da equipe do projeto, notadamente dos professores envolvidos que tiham como tarefa orientar os bolsistas de Mestrado, Doutorado e de Iniciação Científica envolvidos.

Adicionalmente, foram contratados profissionais externos nas áreas em que a UNIRIO não dispunha de formação, notadamente Geografia, Comunicação, Informática, Fotografia, Filmagem, Edição e Montagem em Vídeo Digital, Programação Visual, Webdesign. Estes profissionais foram acolhidos dentro do espírito da equipe compartilhando as informações e contribuindo para o caráter de ensino, pesquisa e extensão impresso no projeto.

Os bolsistas e os profissionais contratados foram estimulados a desenvolverem sub-projetos sendo autores de partes específicas dos mesmos, ficando a responsabilidade e a autoria do produto final a cargo da coordenação geral.

As etnografias audiovisuais dos Museus do Rio serviram de base para programas de TV e documentários sobre o tema.

Os filmes realizados, resultado dos percursos trilhados em oito regiões do Estado do Rio de Janeiro, foram copiados em DVD e distribuídos para ampla difusão.:

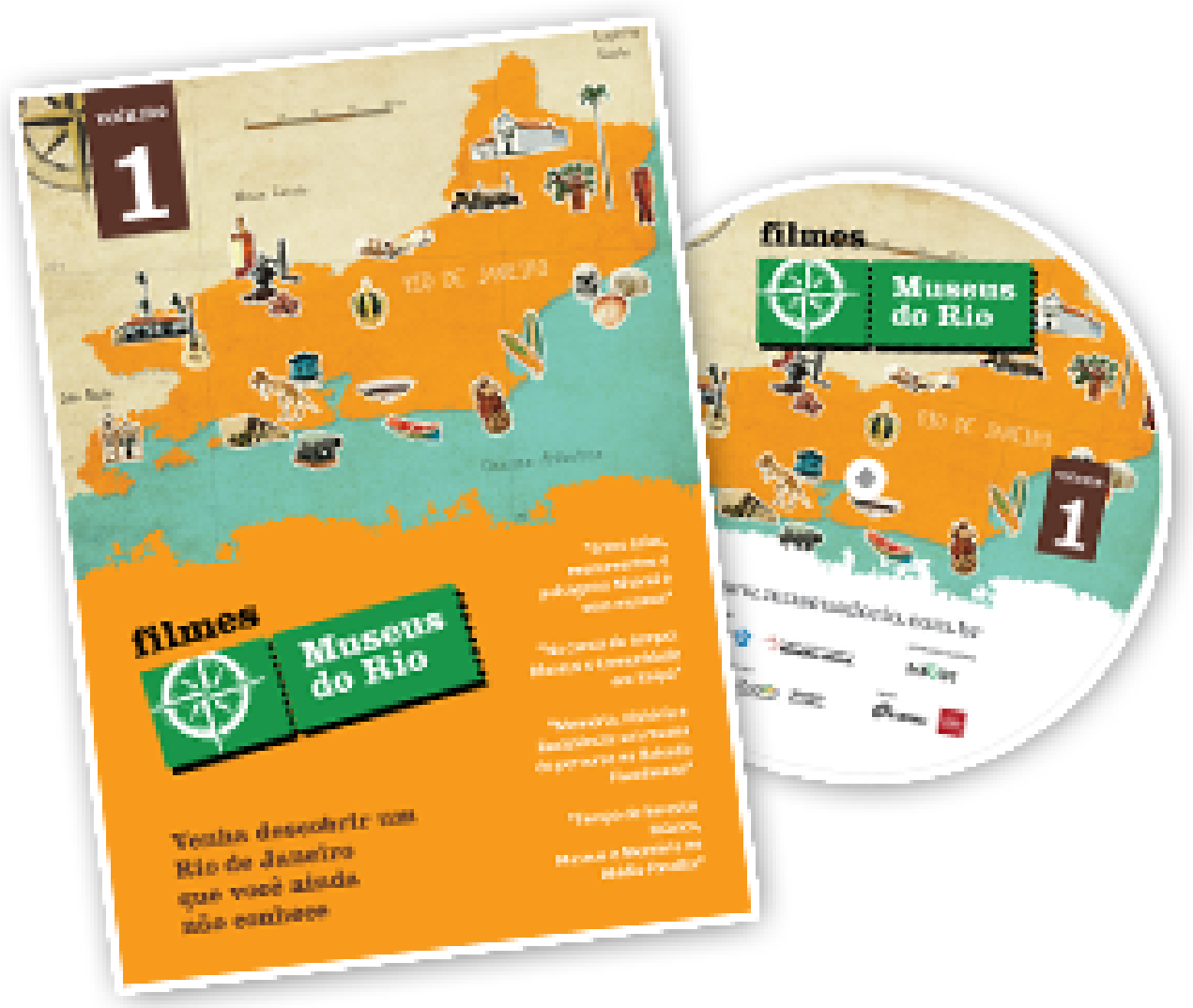




\section{DVD I}

"Entre telas, monumentos e paisagens: Niterói e seus Museus"

"Na canoa do tempo: Museus e Comunidade em Itaipú"

"Memória, História e Resistência:um Museu de percurso na Baixada Fluminense"

"Tempo de Seresta: Música, Museus e Memória no Médio Paraíba"

\section{DVD 2}

"O sagrado, a cidade e o patrimônio: Museus na Costa verde"

"Vestígios diversos em tempos vários: Museus na Costa do Sol

"Café, Ferrovia e Cachaça: Museus no Centro Sul Fluminense"'

"Fragmentos e fontes de memória: Museus no Norte Fluminense"

"Colonização, Império e República: Museus na Região Serrana"

Este filmes vem sendo veiculados também pela TV Alerj e pela TV NBR e inspiraram um novo programa de TV com o título "Museus do Rio", cuja realização é da UNRIO em convênio com a TV Alerj.

Partindo das regiões, traçamos inicialmente sete percursos: Percurso Médio Paraíba; Percurso Costa do Sol; Percurso Centro-Sul; Percurso Metropolitana; Percurso Região Serrana; Percurso Baixadas Litorâneas; Percurso Norte Fluminense.

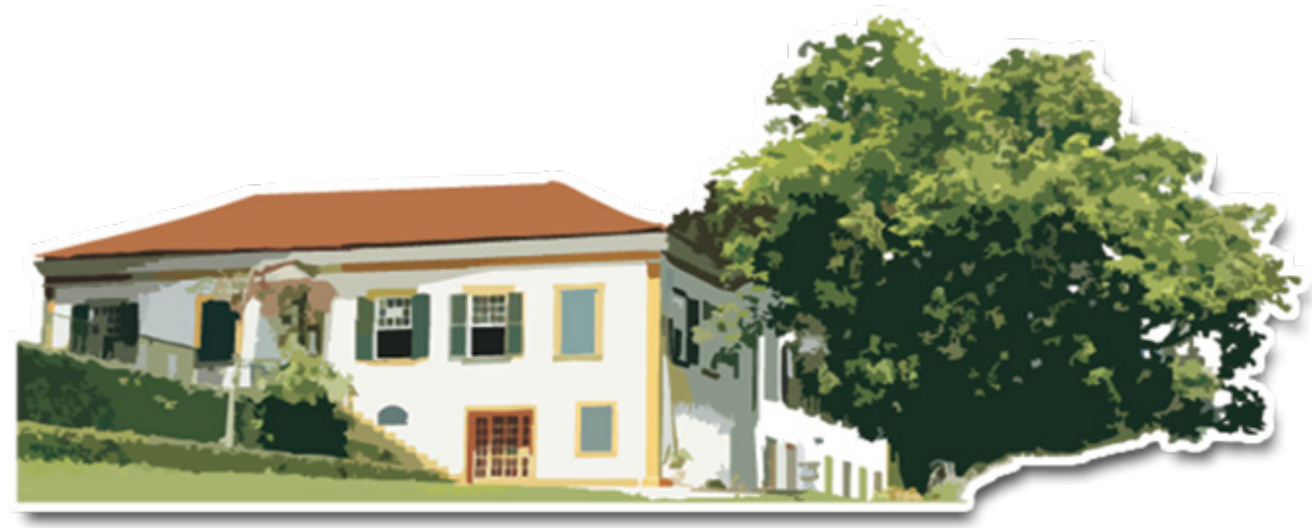




\section{Percurso Médio Paraíba:}

Viajando por pequenas estradas de terra ou pelas grandes rodovias desta região, ainda é perceptível, seja em vestígios nas matas, seja no cheiro que impregna os bares e as paradas para abastecimento, a presença do café, principal produto agrícola que, durante anos, movimentou a economia do lugar e fez surgir as outrora prósperas fazendas. Preservadas por seus proprietários, essas belas e imponentes propriedades nos conduzem a um outro tempo. Além disso, constituem patrimônio de cultura material significativo, com arquitetura singular representativa de um estilo de morar das elites brasileiras do fim do século $\mathrm{XIX}$ e início do século $\mathrm{XX}$. Chamam a atenção especialmente os assoalhos em madeira de lei, os amplos salões, as alcovas e as marcas da religiosidade impressas em oratórios ou até mesmo em pequenas capelas. Belas edificações como as da Fazenda Vista Alegre, a Fazenda Pau d'Alho, a Fazenda Florença e a Fazenda da Bocaina compõem, em Valença, um cenário idílico e trazem a nostalgia de um passado.

Mas, para o viajante em busca dos museus da região, certamente a pequena cidade de Conservatória, distrito de Valença, é parada obrigatória. Nela, a memória é ativada nas canções de seresta e nos rituais das serenatas. Uma memória que se afirma no sentimento dos mais vividos e que se inaugura naqueles mais moços, como se diz no local. Seguindo esse clima musical, uma experiência imperdível é participar das serenatas que são executadas às sextas-feiras e aos sábados, depois das 23 horas, na Rua das Flores, no bairro da Felicidade. Seresteiros, poetas, cantadores misturam-se aos visitantes e turistas ao som do cancioneiro da música brasileira de amor. Trata-se de um movimento singular e espontâneo criado e mantido por moradores da cidade que preserva expressivo patrimônio imaterial brasileiro. Dele, um vasto acervo reunido por seresteiros e visitantes gerou um pequeno museu que ali funcionou por anos, o Museu da Seresta e da Serenata. Hoje, esse acervo pode ser visitado na Casa de Cultura de Conservatória. Dois outros museus, também iniciativas de particulares, completam esse clima de encantamento e sonoridade da boa música, homenageando Vicente Celestino e Gilda de Abreu e o Museu Sílvio Caldas, Gilberto Alves, Nelson Gonçalves e Guilherme de Brito.

Em torno das potencialidades da memória do cancioneiro popular, o movimento da seresta e da serenata vem fomentando uma autêntica "economia criativa”. São bares, restaurantes, pousadas, lojas de souvenir e até um pequeno estúdio de fotografia onde o visitante é convidado a se deixar fotografar com roupas antigas, entrando no clima de outras épocas, como a Era do Rádio e o tempo dos primeiros estúdios de cinema no Brasil.

Depois de havermos nos deleitado com os museus que homenageiam compositores, poetas e artistas consagrados da vida cultural brasileira, há ainda outras opções que valem a visita.

O Museu da Roça é uma iniciativa interessante, sobretudo para aqueles que anseiam por uma pausa na agitação da vida urbana. Criado pela Associação da Feira da Roça, que existe há 27 anos, está localizado no centro da cidade de Quatis, o museu foi inaugurado em 2004, ocupando uma antiga casa construída em adobe, em 1899. É uma viagem no tempo entrar em contato com utensílios antigos como as máquinas de costura e os ferros de passar a carvão, presenças 
outrora obrigatórias nos afazeres domésticos na área rural. Promove nos segundos e quartos domingos do mês a Feira da Roça, aberta a todos os visitantes, com barracas com produtos locais, almoço e música para dançar.

O Museu de Arte Moderna em Resende é um capítulo à parte. Fundado em 1950 pelo escritor Marques Rebelo, ocupa uma casa espaçosa no Centro Histórico de Resende e é mantido pela Prefeitura, que fez a aquisição do primeiro quadro, um óleo de Iberê Camargo. Guarda obras de Tarsila do Amaral, Santa Rosa, Guignard, Lasar Segall, Liesler, Alfredo Ceschiatti, Poty. E também abre os dois salões principais para cursos, palestras, espetáculos de música e teatro, sessões de cinema e lançamentos de livros. As visitas podem ser mediadas mediante agendamento.

Por fim, entre outras opções de museus na região, deparamo-nos com o Museu Finlandês da Dona Eva em Penedo, Itatiaia. Foi uma oportunidade única de ver de perto contribuições culturais dos finlandeses que vieram para o Brasil, estimulados pelas políticas de imigração do começo do século $X X$ : tapeçarias feitas em teares manuais, trajes típicos usados em festas e ocasiões especiais; objetos de artesanato confeccionados em casca da árvore bétula; bonecas finlandesas e uma coleção de livros, revistas, folhetos e fotografias que estimulam a pesquisa histórica e também a vontade de se aventurar por este país tão distante e tão pouco conhecido dos brasileiros.

Com museus tão diversos, percorrer o Médio Paraíba nos levou à descoberta de uma variedade de opções que se traduz numa pluralidade de memórias espalhadas por seus municípios.

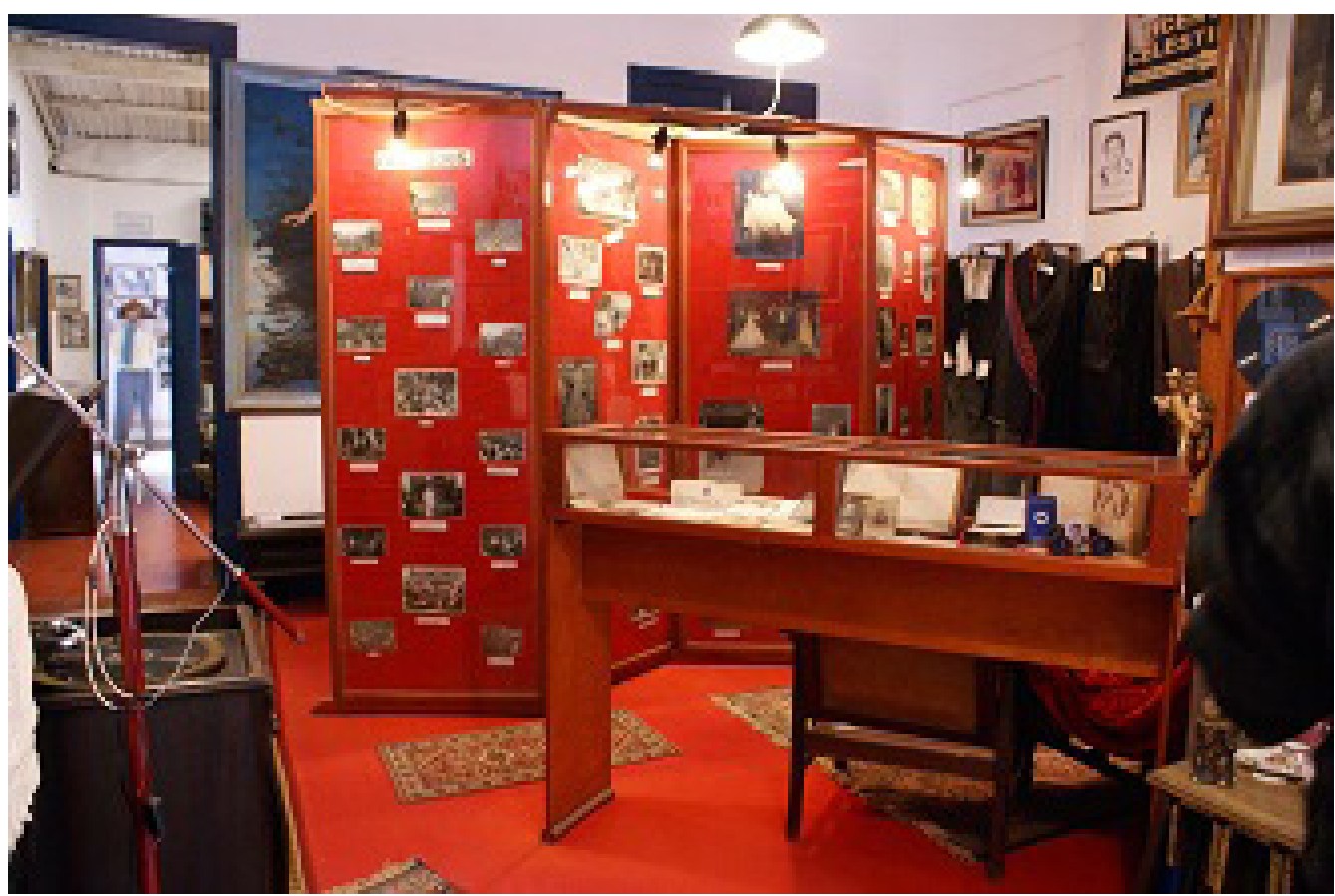

Museu Vicente Celestino e Gilda de Abreu - Conservatória - Valença, RJ 


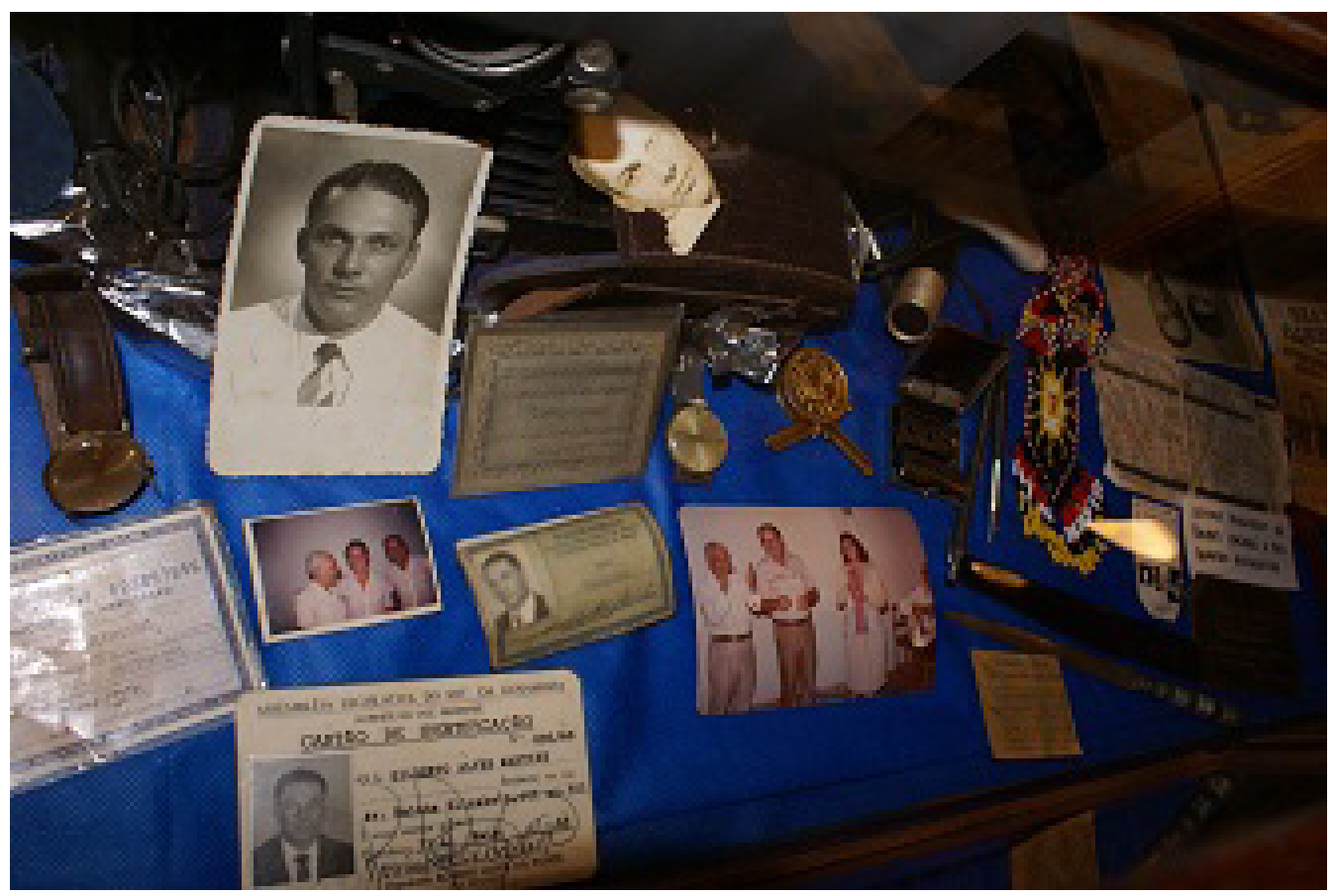

Museu da Seresta e da Serenata - Conservatória -Valença, RJ

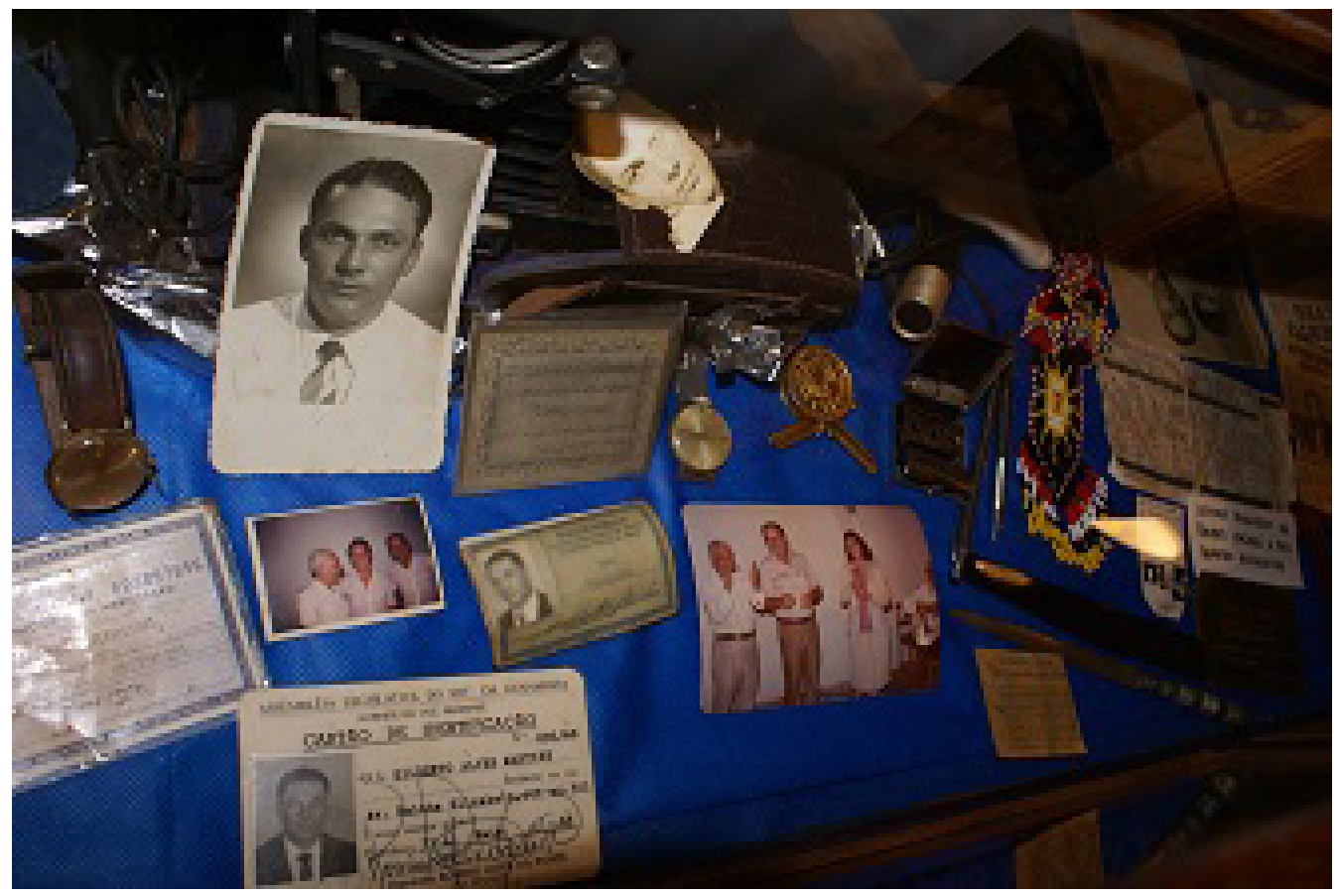

Museu Silvio Caldas, Gilberto Alves, Nelson Gonçalves e Guilherme Brito - Conservatória - Valença, RJ 


\section{Percurso Costa Verde:}

Para conhecer as diferentes memórias que os museus da Costa Verde poderiam nos revelar, atravessamos lugares paradisíacos, onde a serra teimava em competir pela primazia estética com o mar da Baía da llha Grande. Fixamos como destino Paraty, simpático município que, desde 1966, foi elevado à categoria de Monumento Nacional pelo Instituto do Patrimônio Histórico e Artístico Nacional (Iphan). Ao percorrermos o Bairro Histórico de Paraty, fomos tomados pela sensação de estarmos no passado. A mais antiga edificação religiosa da cidade, a Igreja de Santa Rita, que teve sua construção iniciada em 1722, abriga o Museu de Arte Sacra de Paraty. O museu reúne acervo proveniente das irmandades religiosas e das igrejas de Nossa Senhora dos Remédios, Nossa Senhora do Rosário, Nossa Senhora das Dores, além dos Passos da Paixão e capelas da zona rural. Nas coleções de imaginária e de prataria dos séculos XVII, XVIII e XIX, destacam-se as imagens da padroeira de Paraty, Nossa Senhora dos Remédios, e o Grupo da Sagrada Família, com rara iconografia de Nossa Senhora da Expectação; as alfaias expostas em caixa-forte/vitrine; as coroas e os cetros usados nos cortejos das festas do Divino Espírito Santo e de Nossa Senhora do Rosário e São Benedito e a custódia que conduz o Santíssimo Sacramento na procissão de Corpus Christi. Apesar de musealizados, esses objetos retomam seus status e usos originários ligados às práticas e tradições religiosas ao serem devolvidos às irmandades que os carregam nas procissões em dias festivos pela cidade.Além da guarda e conservação das coleções, o museu promove a pesquisa e a divulgação do testemunho histórico, cultural e religioso da comunidade paratiense.

No alto do Morro da Vila Velha, Morro de São Roque, Morro do Pontal e depois Morro do Forte, desponta uma das mais belas vistas da cidade e da baía de águas calmas, por onde embarcava o ouro vindo das minas rumo à cidade do Rio de Janeiro. Como um presépio à beira-mar, no Centro Histórico a imponente Igreja da Matriz contrasta com o casario colonial, a maioria requalificada como pousadas, restaurantes e lojas de artesanato.

Com acesso apenas aos pedestres, nas ruas de pedras irregulares, produto e memória da riqueza produzida pelo caminho do ouro, levas de turistas embarcam rumo às centenas de ilhas e de praias espalhadas pela Baía de Paraty.

É ainda no Morro do Forte, lugar que recebeu o primeiro núcleo de povoamento em Paraty, que se encontra o museu Forte Defensor Perpétuo, administrado pela prefeitura.A fortificação abriga um museu de tradições populares de Paraty e, assim como o restante da cidade, dialoga fortemente com o período em que o Brasil era uma colônia de Portugal. Graças ao isolamento de mais de um século, a cidade, um dos mais importantes caminhos do ouro durante a Colônia (I530-I8I5), manteve preservados seu traçado urbano, arquitetura e tradições. À época, um complexo composto de fortes, fortins e baterias defendiam a cidade e seu porto dos constantes ataques de corsários e piratas. Estudo feito no século XIX relata que todas essas fortificações foram desarmadas entre 1828 e 1831 . Por volta de 1885 , já estavam em ruínas.

Nossa viagem pela Costa Verde prosseguiu em direção ao município vizinho de Angra dos Reis. O Museu de Arte Sacra de Angra dos Reis, sediado nas dependências da Igreja de Nossa Senhora da Lapa e Boa Morte é considerado 
um dos mais importantes do estado em matéria de arte sacra. Seu acervo, tombado pelo Iphan, reúne cerca de dois mil itens distribuídos em coleções de imaginária, prataria e indumentária, que datam do século XVII ao início do século XX. Esse acervo é oriundo das irmandades já extintas do Santíssimo Sacramento, de Nossa Senhora do Rosário, de São Miguel e Almas e de Nossa Senhora da Conceição; das igrejas localizadas na llha Grande, Mambucaba,Ariró, Bracuí, Ribeira e Jacuecanga, assim como do culto doméstico muito particular que fez surgir algumas imagens de cunho popular tradicional na região. Criado em 1992, o museu é um misto de templo sagrado e espaço cultural. Desde então, todo ano é realizada no museu uma exposição temática diferente, com o fim de fazer circular o importante acervo sob a fiscalização do Iphan e manutenção do município.

Por fim, seguimos em direção à Mangaratiba para conhecer precioso acervo de conchas, preservado no Museu Municipal de Mangaratiba. Resultado do esforço de colecionamento e pesquisa de um morador do local, o "Doutor Carlitos", como é conhecido, esse acervo malacológico representa uma curiosa forma de contribuir para a preservação da biodiversidade na região. Cerca de I.200 espécies de conchas evidenciam a diversidade da fauna de moluscos numa região de pulsante biodiversidade.

História, natureza e tradições populares interagem e se conjugam num dos percursos mais belos do estado.

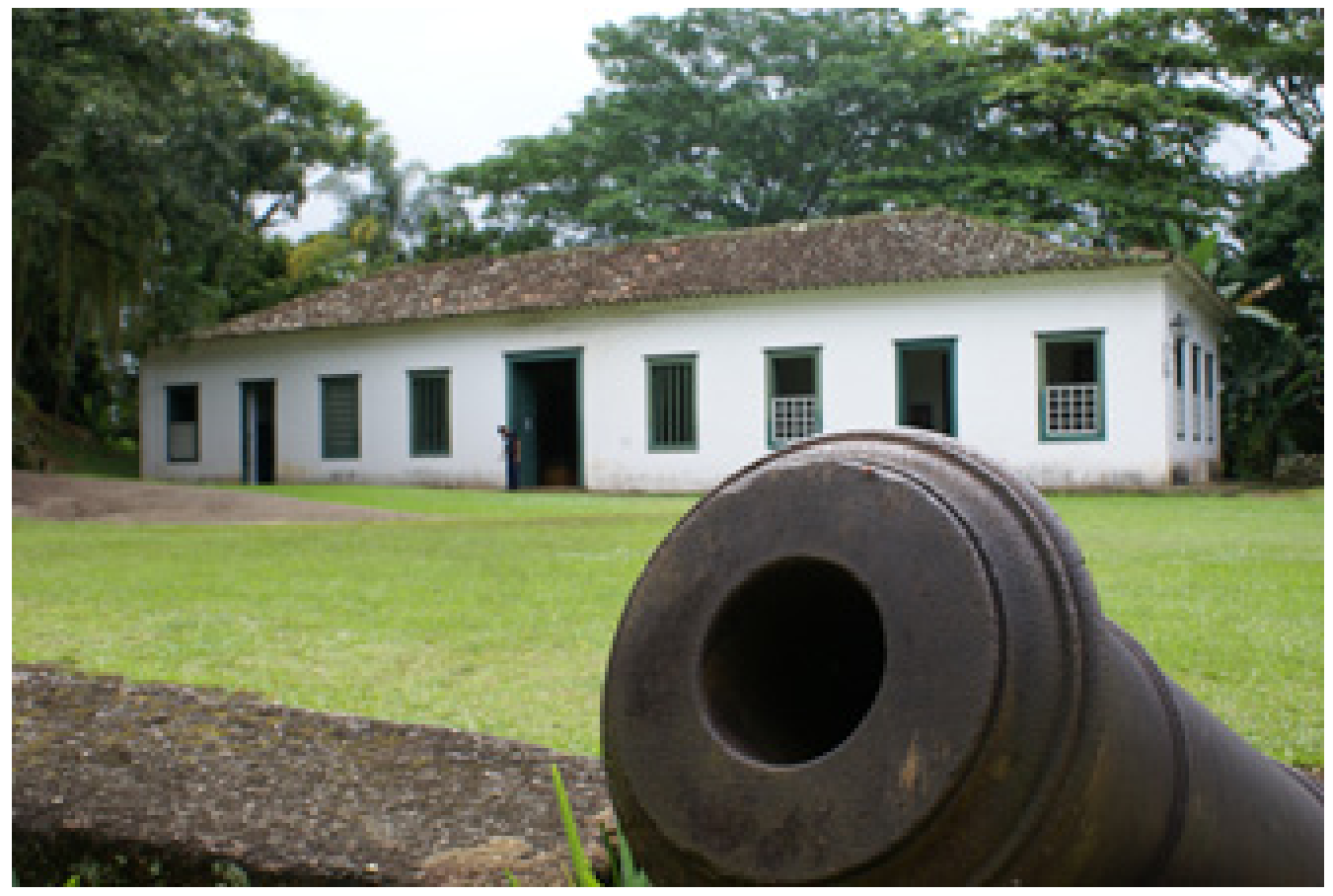

Museu Forte Defensor Perpétuo - Paraty, RJ 

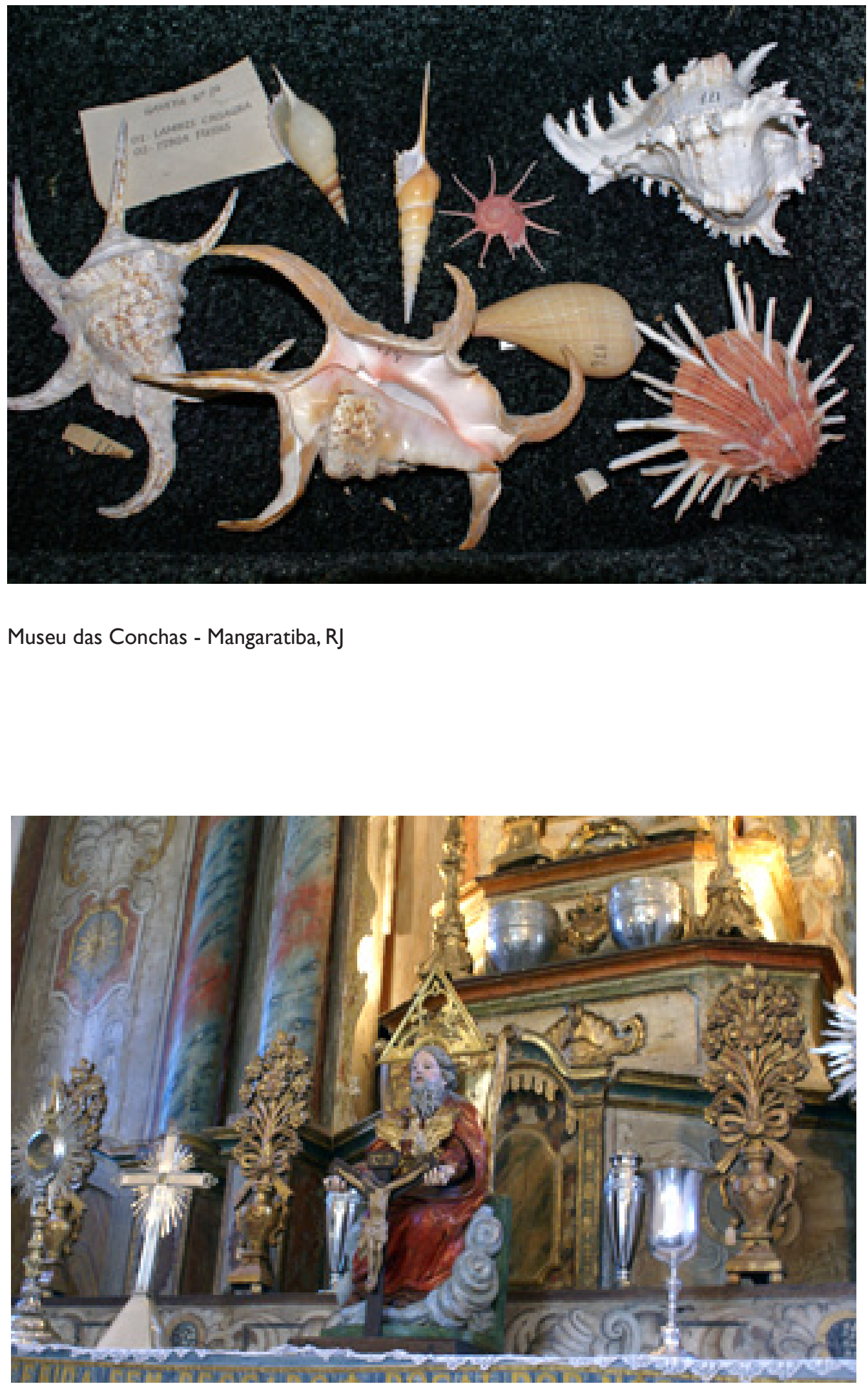

Museu de Arte Sacra de Angra dos Reis - Angra dos Reis, RJ 


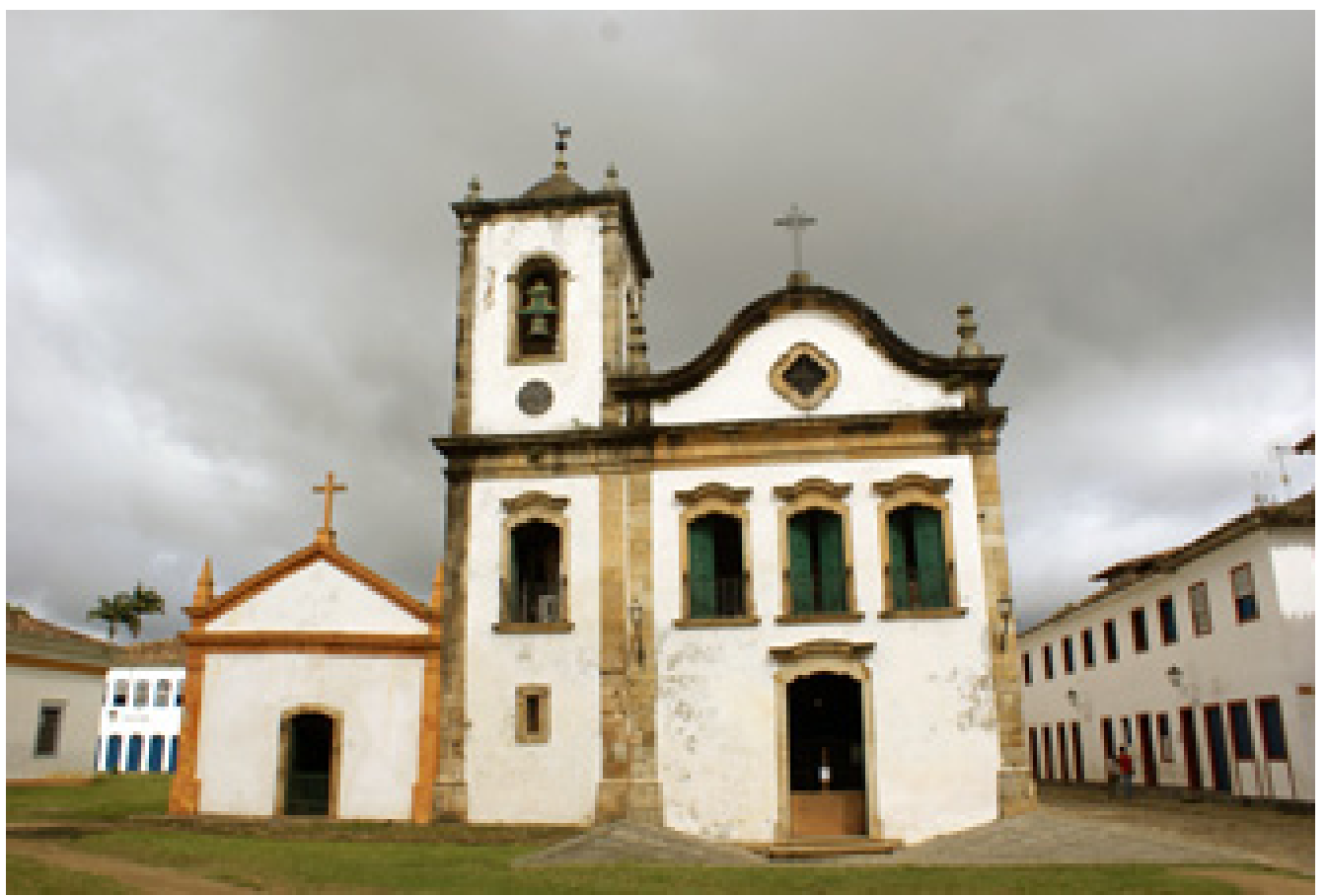

Museu de Arte Sacra de Paraty - Paraty, RJ

\section{Percurso Região Serrana:}

Seguimos para a Região Serrana, conhecida pelo clima ameno e a exuberância das matas. Visitamos a cidade de Petrópolis muito reconhecida por seu passado ligado ao Império. A arquitetura da cidade nos chamou a atenção.

Conhecemos a Casa do Colono, construída por colonos alemães em 1847, cujo alicerce é de pedra bruta e as paredes são de pau-a-pique.As ruas do quarteirão têm nomes que se referenciam aos colonos alemães.

De lá, seguimos para o Museu Imperial, importante símbolo da cidade e um dos museus mais visitados do Brasil. O museu trata da vida imperial e desse passado repleto de símbolos reais, coroas, roupas, pinturas, louças, prataria.

Depois fomos para o Palácio Rio Negro, construído em 1889, ano da proclamação da República. O Barão do Rio Negro deixou o palácio por motivos desconhecidos. A casa ficou fechada até 1903 quando o presidente Deodoro da Fonseca transferiu momentaneamente a capital da província para Petrópolis.

Por último, visitamos a Casa de Santos Dumont na Rua do Encanto, no Morro do Encanto e chamada por Santos Dumont de "casa Encantada". Trata-se da única residência que Santos Dumont teve no Brasil.

Em cada um destes museus, fizemos longas entrevistas com diretores, pesquisadores, estudiosos da história local. 


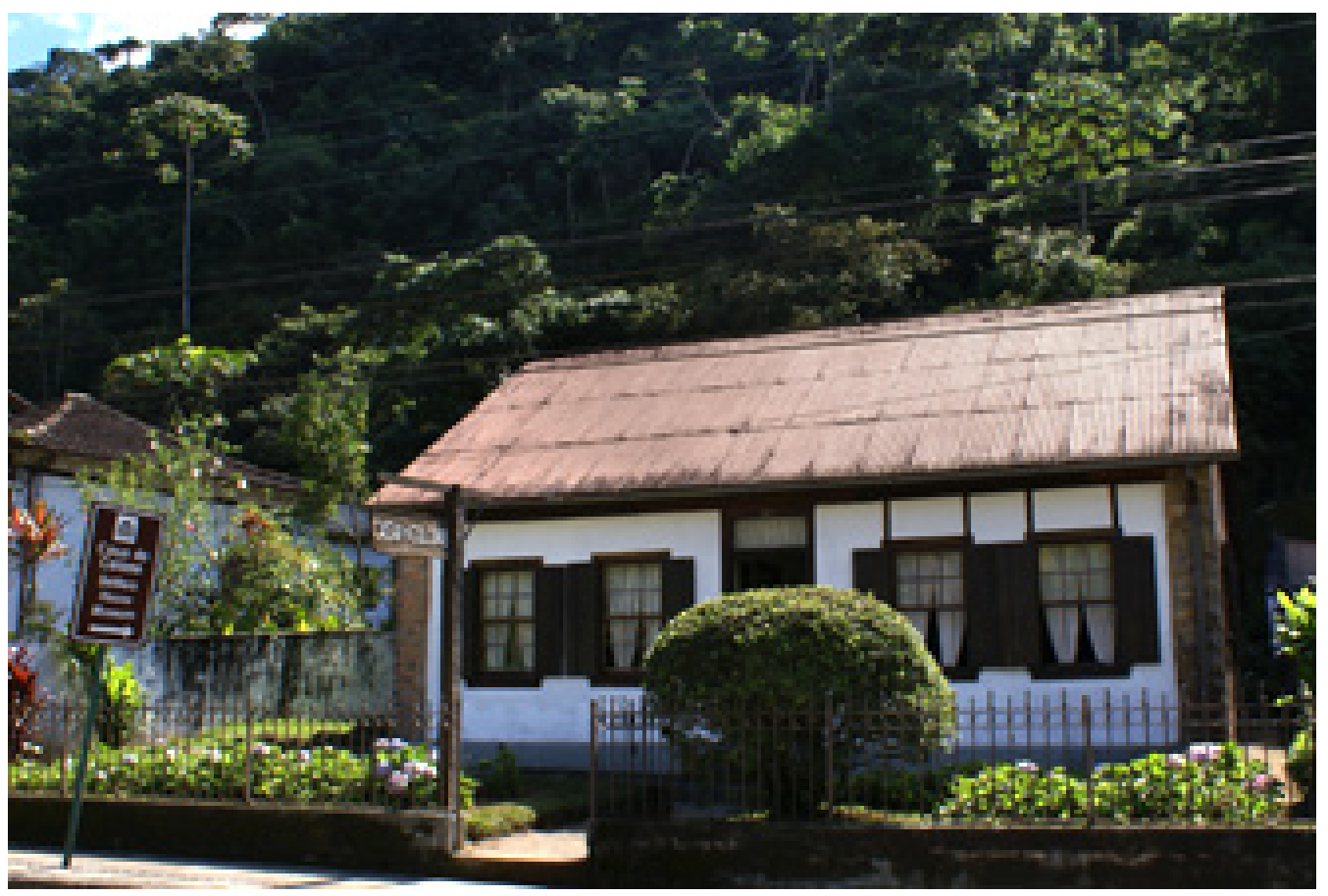

Museu Casa do Colono - Petrópolis, RJ

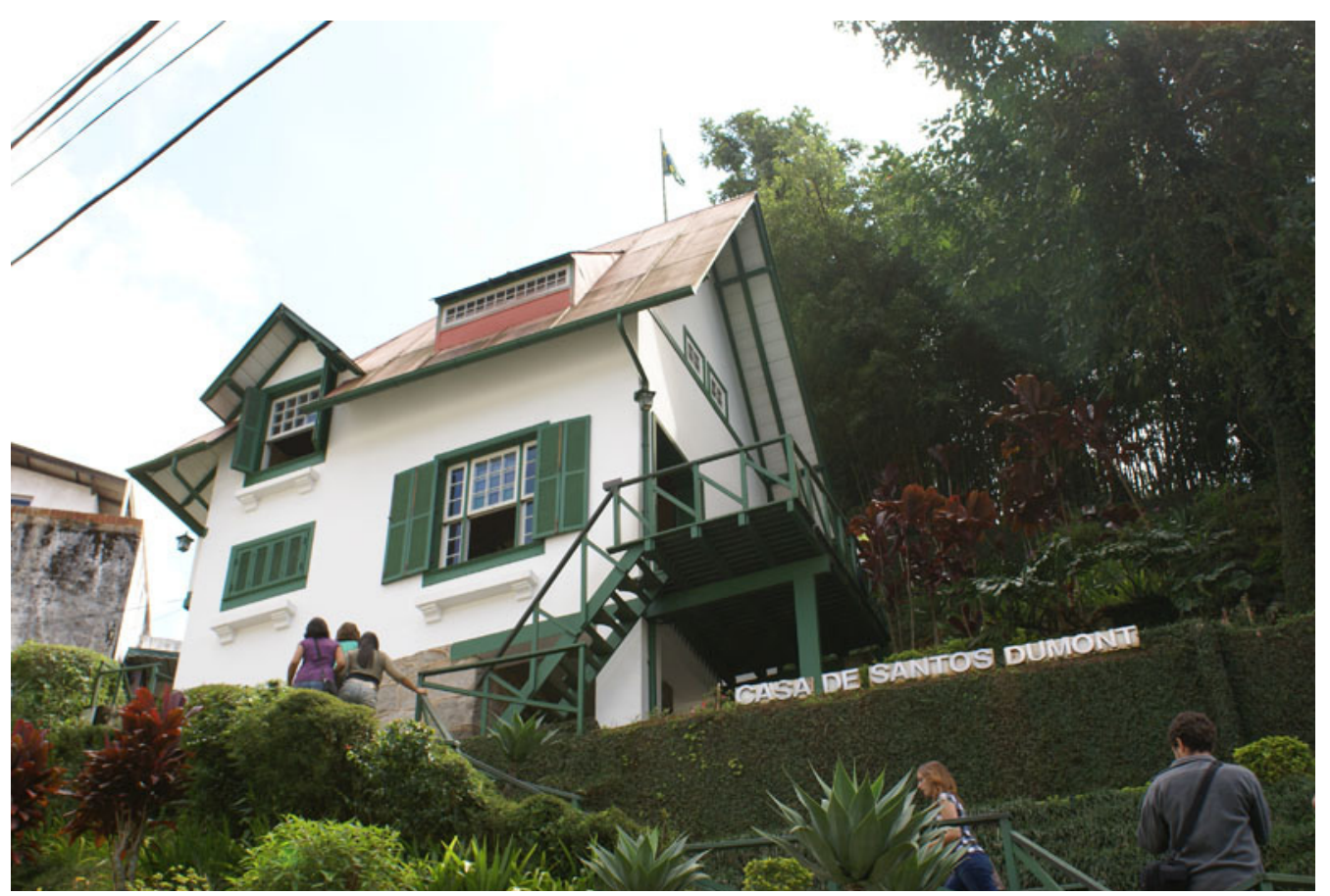

Museu Casa de Santos Dumont - Petrópolis, RJ 


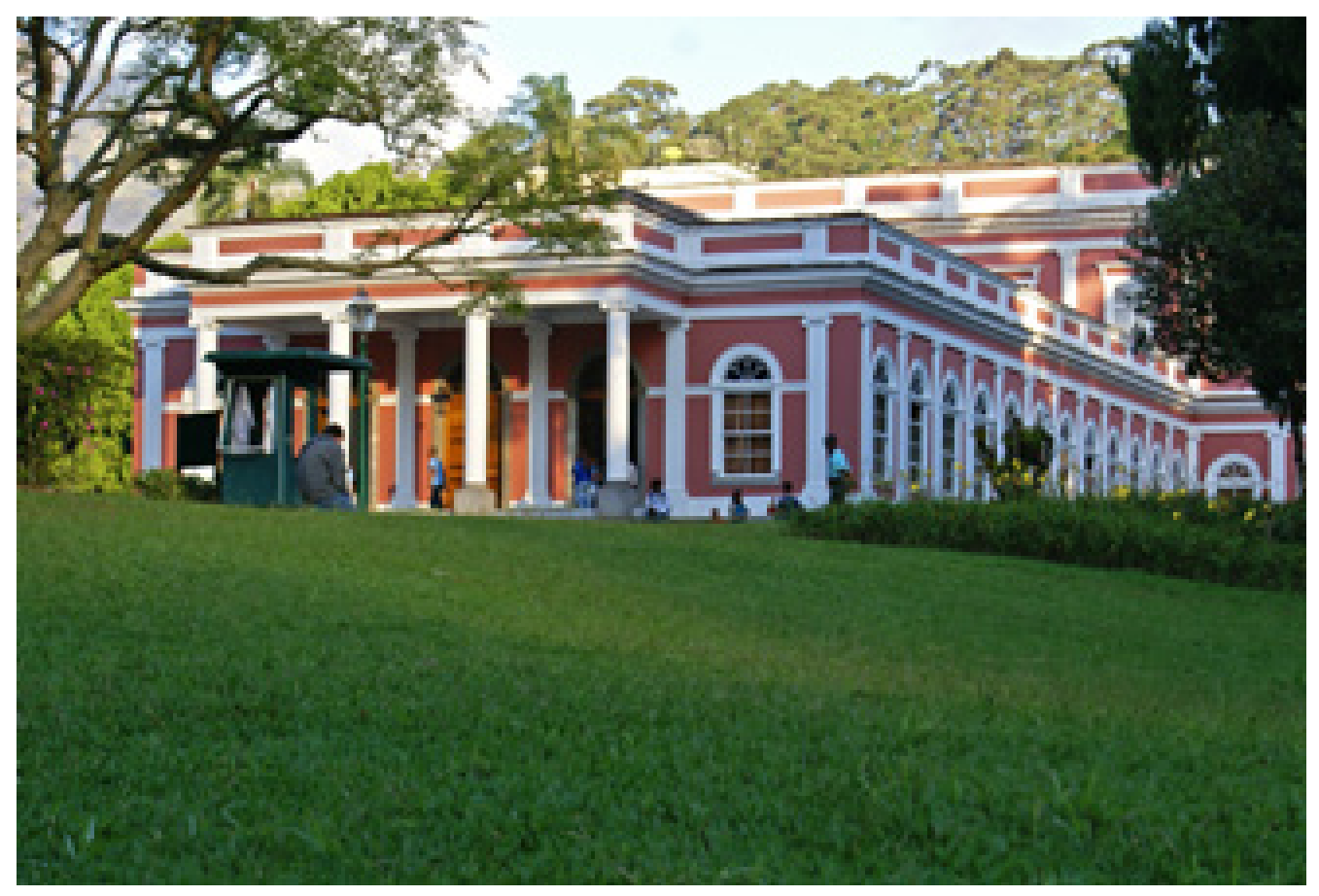

Museu Imperial - Petrópolis, RJ

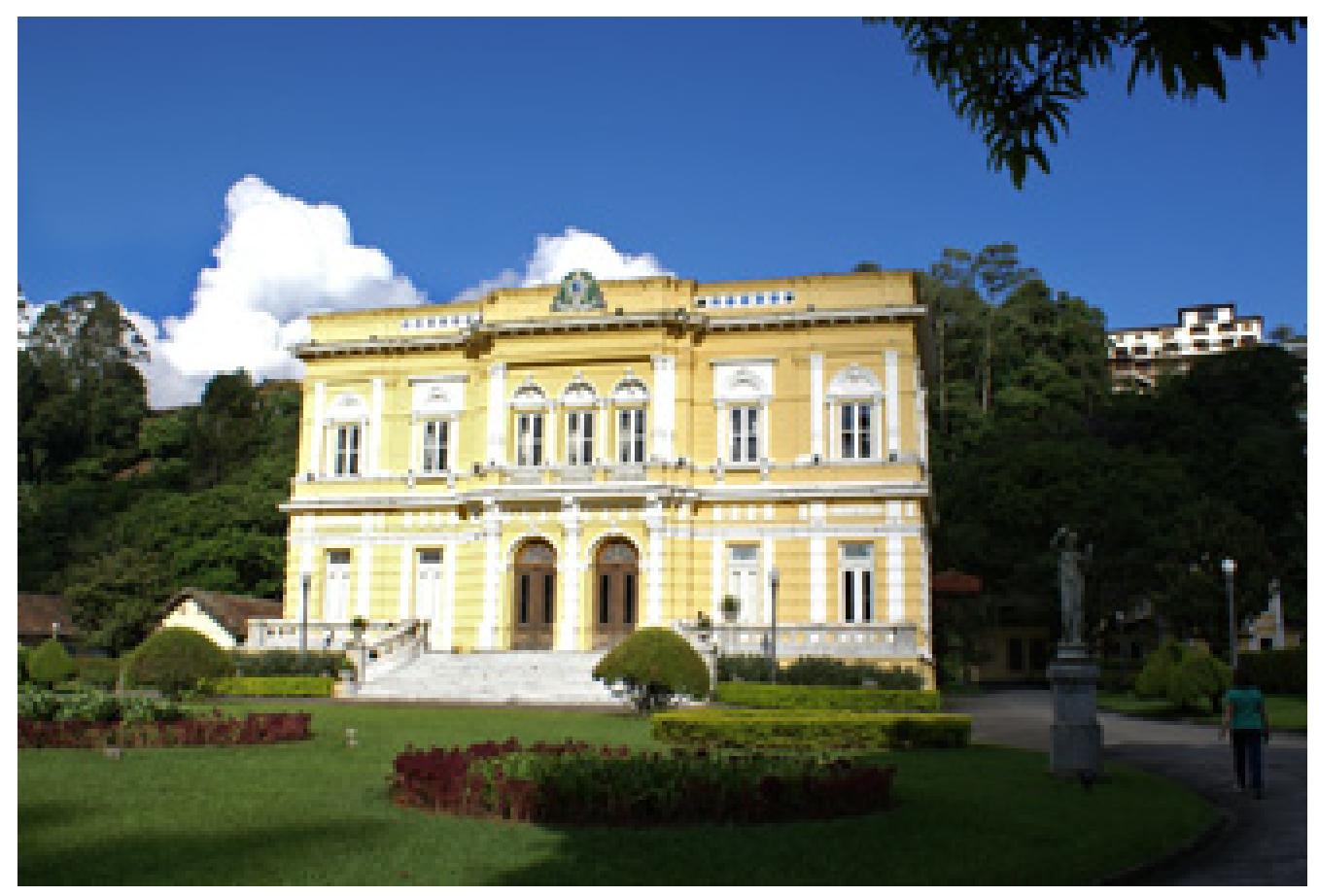

Palácio Rio Negro - Petrópolis, RJ 


\section{Percurso Centro-Sul:}

Percorrer o legendário Vale do Paraíba é entrar em contato com um território que representou uma das bases de sustentação econômica e política do Império brasileiro e de parte da República. Ali se cultivou, durante décadas, um dos maiores produtos de exportação brasileira, o café. Por esse motivo, o vale chegou a ser conhecido como o Vale do Café.

Em torno da economia cafeeira, floresceram cidades e toda uma cultura das grandes fazendas, onde uma classe senhorial afirmou-se e enriqueceu-se: os "barões do café". As fontes dessa riqueza emanavam da mão de obra dos escravos trazidos da África e que, em meados do século XIX, atingiram a cifra de milhares.

Há muitos vestígios históricos no Vale do Café. A cidade de Vassouras concentra significativo patrimônio: além dos grandes casarões, o Museu Casa da Hera destaca-se na sua paisagem. A visita a esse museu, antigo local de moradia de uma das mulheres mais ricas e avançadas do Império, Eufrásia Teixeira Leite, é uma rara oportunidade para conhecer de perto vestígios da intimidade da vida dos barões e baronesas do café, por meio dos mais de três mil objetos expostos que pertenceram à família Teixeira Leite.

Percorrendo a casa de Eufrásia, personagem singular em uma sociedade que não reservava às mulheres um papel de protagonismo, aprendemos um pouco sobre a sociedade da época e, em particular, sobre essa mulher que rompeu barreiras e notabilizou-se por grande tino comercial, chegando a multiplicar sua fortuna em investimentos financeiros na Europa.

Mas, e as memórias dos escravos? Onde habitam, em Vassouras, os vestígios da imensa população negra que povoou o Vale do Café no século XIX? Um desses lugares é o Memorial Manuel Congo, erigido no local onde o líder quilombola Manuel Congo foi enforcado por aqueles que faziam a repressão às revoltas dos escravos. O Memorial é muito simples, mas impactante em virtude de seu grande potencial evocativo da memória da escravidão, por tantas vezes silenciada na História do Brasil. Em seu entorno, em algumas ocasiões, abre-se a roda para manifestações da cultura afro-brasileira, valorizando o patrimônio imaterial dos atuais descendentes dos antigos trabalhadores do café.

Abertas à visitação, há ainda diversas fazendas que podem ser visitadas, mediante agendamento prévio, e onde permanece viva a aura da riqueza produzida no século XIX: Fazenda Santa Eufrásia, Fazenda Cachoeira Grande, Fazenda Galo Vermelho, Fazenda Cachoeira do Mato Dentro, Fazenda Mulungu VermeIho, Fazenda São Fernando, Fazenda do Secretário, Fazenda São João da Barra.

Seguindo para Miguel Pereira, cidade bucólica de veraneio, dois museus são particularmente interessantes. $O$ primeiro, o Museu Ferroviário, fica localizado na antiga Estação Ferroviária de Miguel Pereira, criada em 1898 pela Estrada de Ferro Melhoramentos, inicialmente com o nome de Estação da Estiva. Nos anos 1990, os moradores se organizaram pela preservação desse espaço de memória que havia sido comprado por uma rede de supermercados.A Prefeitura aderiu ao movimento social, embargando a obra e comprando a área que passou a abrigar o museu e preservar a memória coletiva dos antigos ferroviários e suas famílias.

O museu é muito simples, e os objetos que ali estão patrimonializados, ainda que sem uma proposta clara de exposição, são muito curiosos e evocativos de uma história importante que perdurou por quase um século. São testemunhos da malha ferroviária que interligava os diversos municípios e foi crucial na ocupação humana 
de toda a região. Lá estão uma antiga locomotiva, vagões, bancos, sinos, dormentes de estradas de ferro, instrumentos de trabalho os mais variados, carteiras de trabaIho dos antigos ferroviários, fotografias e um sem-número de objetos que perderam seu valor de uso e hoje são lugares de memória de um mundo que já se foi.

Num outro recanto, ainda em Miguel Pereira, o Museu Francisco Alves relembra aquele que ficou conhecido como o Rei da Voz. Os mais jovens certamente não saberão quem foi esse cantor. Mas, os objetos ali expostos nos trazem a memória de uma era importante para a Música Popular Brasileira: a chamada "era do rádio", em que muitos talentos musicais despontaram e ganharam celebridade. Dono de uma voz firme e potente, Francisco Alves começou sua carreira em 1918, cantando uma marchinha carnavalesca do compositor Sinhô, que fez muito sucesso na época: “O Pé de Anjo”. Discos, partituras, microfones, roupas, rádios dos anos 1940, instrumentos musicais e ampla iconografia do artista estão ali reunidos. E o museu, gerido pela prefeitura, assume o papel de tirar do esquecimento e homenagear Francisco Alves, talvez numa atitude de retribuição pelo fato de o cantor, já famoso, haver frequentado a cidade de Miguel Pereira e difundido suas qualidades.

Há ainda muito a descobrir nesta região de grande riqueza do ponto de vista histórico e patrimonial. Vale destacar o Parque Ecológico e Ambiental de São João Marcos, em Rio Claro, primeiro sítio arqueológico urbano do país.

Por fim, alguns museus curiosos e com acervos muito interessantes, como o Museu da Cachaça, em Paty do Alferes, criado por um colecionador, encontram-se abertos à visitação pública nos fins de semana. Quem sabe, em um futuro próximo, será possível a criação de outros museus que expressem histórias tão significativas?

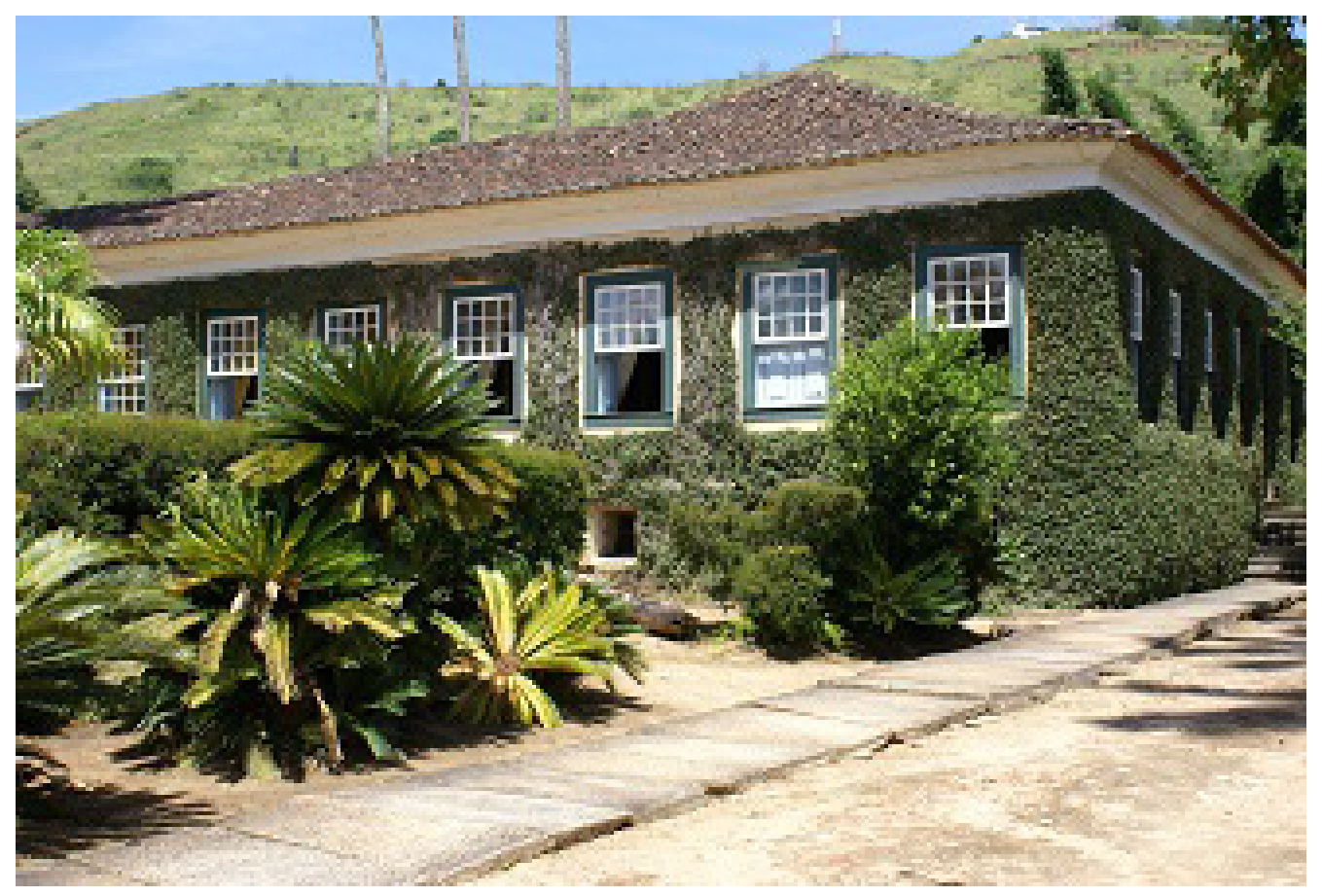

Museu Casa da Hera - Vassouras, RJ 


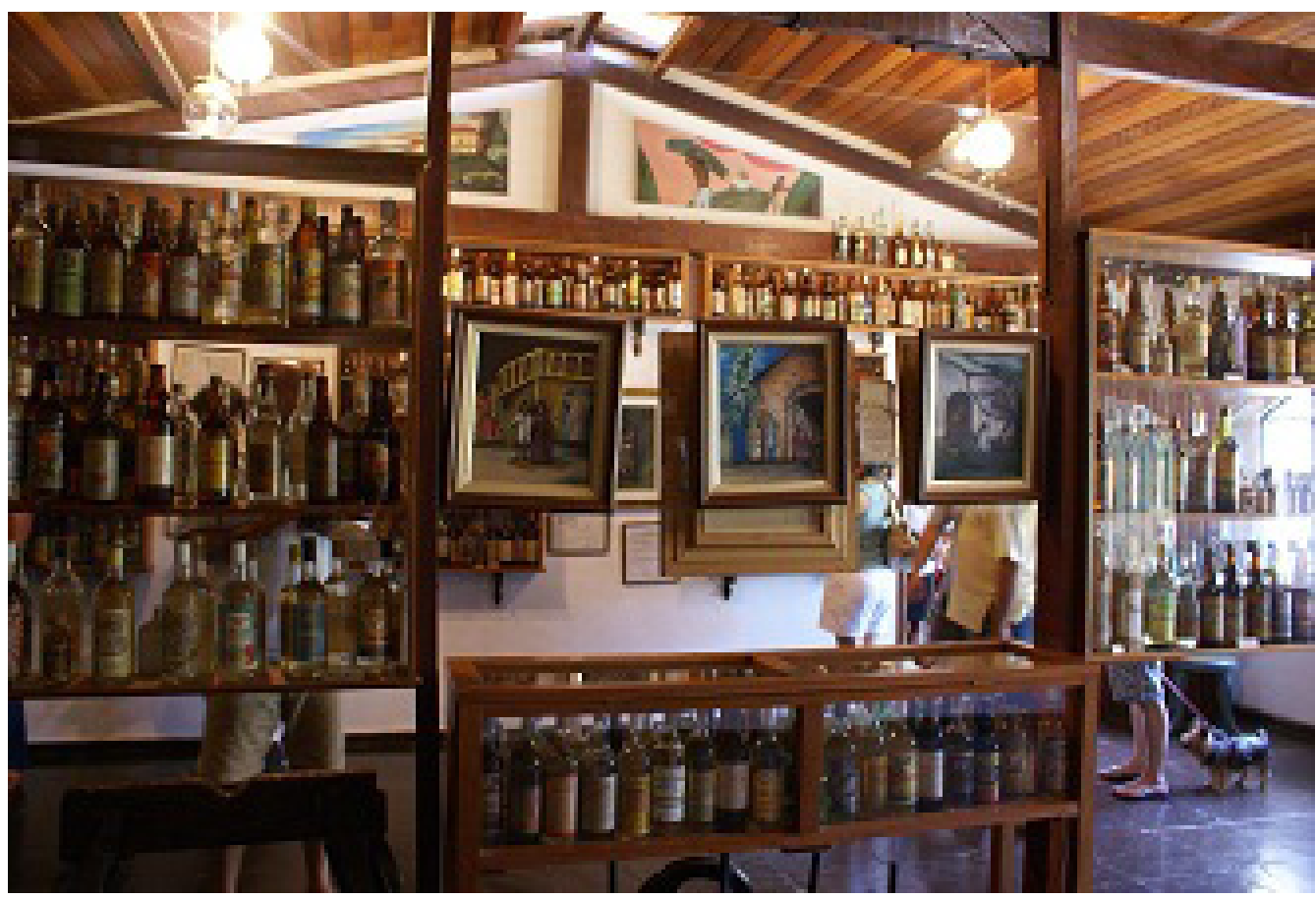

Museu da Cachaça - Paty do Alferes, RJ

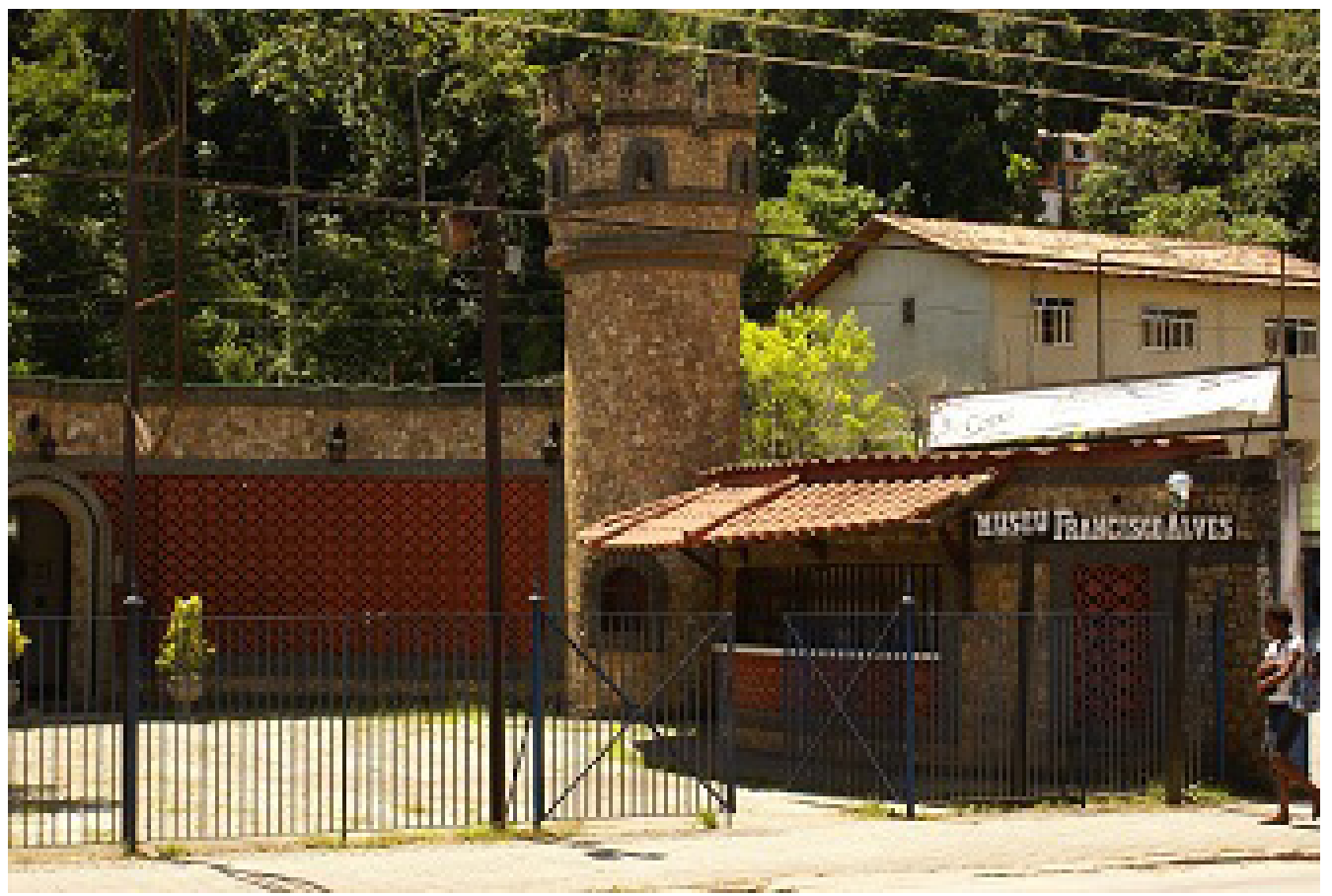

Museu Francisco Alves - Miguel Pereira, RJ 


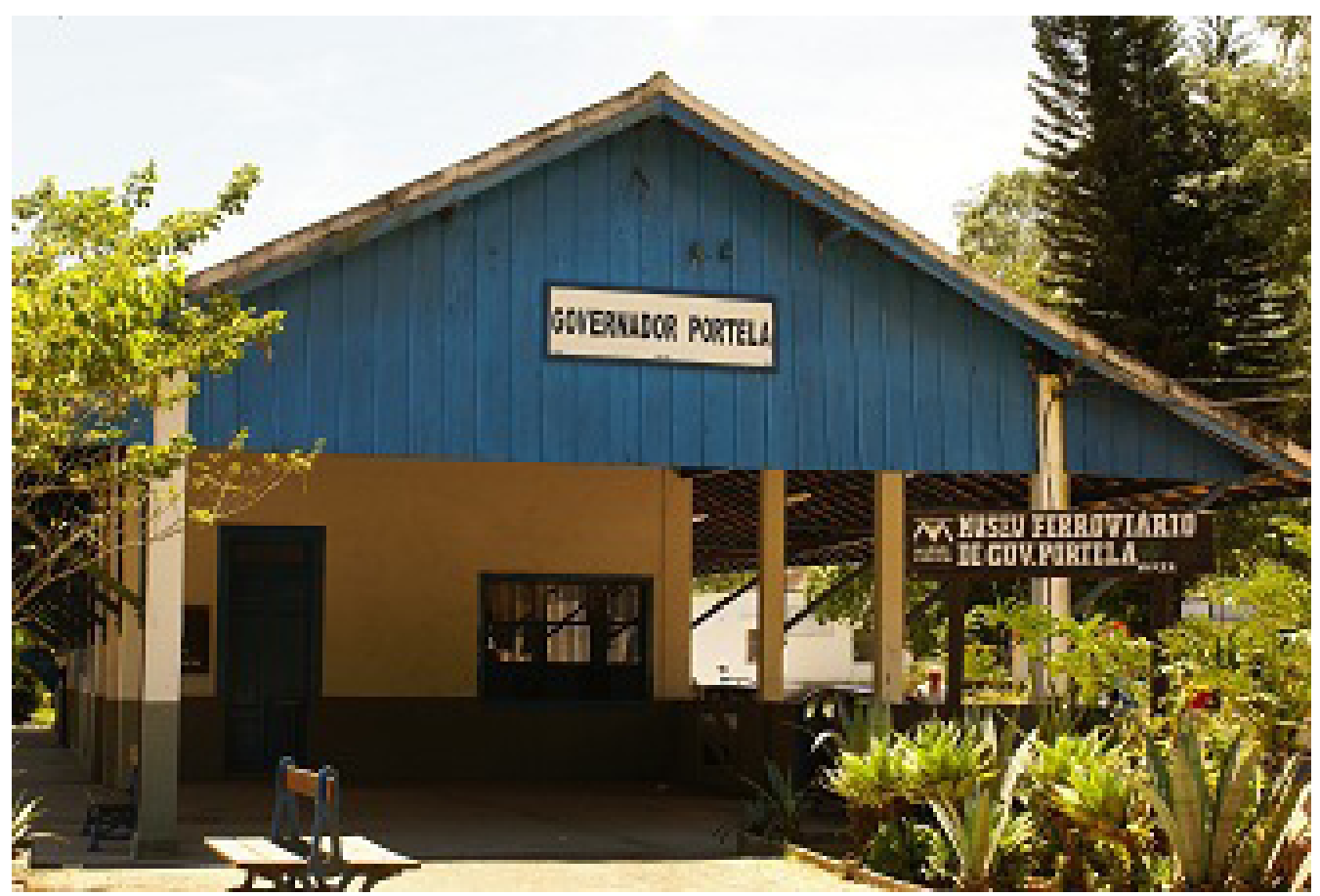

Museu Ferroviário Miguel Pereira - Governador Portela - Miguel Pereira, RJ

\section{Percurso Região Metropolitana:}

Para entrar em contato com os museus da Região Metropolitana, é preciso construir roteiros específicos, pois esta é a região que congrega maior número de municípios. Num primeiro momento e, levando em consideração o objetivo de percorrer museus pouco conhecidos, excluímos o percurso da cidade do Rio de Janeiro e elegemos dois percursos alternativos, um focalizando o município de Niterói e outro focalizando o município de Duque de Caxias.

\section{Percurso I: Niterói e arredores}

No município de Niterói, encontramos uma grande concentração de museus, certamente pelo fato de ter sido, durante décadas, a capital do antigo estado do Rio de Janeiro. Partindo do Rio, nosso percurso teve início ao cruzarmos a ponte em direção a Niterói, cuja vista da Baía de Guanabara é deslumbrante, com destaques na paisagem para navios ancorados no porto, a bela Ilha Fiscal e os contornos dos morros sobressaindo no horizonte.

Na região do Ingá, uma concentração de museus e casas históricas chamou nossa atenção. O mais importante é sem dúvida o Museu do Ingá, grande palacete que serviu de sede de governo até 1975, nos anos em que Niterói foi capital do estado, e que, hoje, abriga um importante acervo de arte, além de laboratórios e oficinas de gravura e educação artística.

Um pouco adiante, visitamos o Museu Antonio Parreiras, que funcionou como casa e ateliê deste que foi um dos mais bem-sucedidos pintores do início do século $X X$. Tanto a casa quanto o ateliê conservam ainda as marcas de seu proprietário, inspirando o visitante a exercitar a imaginação e remontar aos velhos tempos em que a casa respirava arte e criação. Seu acervo de pinturas é 
precioso, guardando as principais obras de Parreiras.Algumas são monumentais, como a tela exposta em seu ateliê. Outras, em menor tamanho, focalizam temas ligados à natureza ou associados à experiência criativa do próprio pintor, que é autorretratado em diferentes fases da vida, sempre pintando ao ar livre, sua maior paixão.

Bem próximo dali, está o Solar do Jambeiro, edificação arrojada que serviu de residência a grandes empresários e apresenta em sua fachada expressivo acervo de azulejos de padrão do Brasil. Em seu entorno, um jardim bucólico nos acolhe e nos permite um pequeno momento de contemplação e descanso.

Quase em frente ao Solar, está o Museu Municipal Janete Costa, que abriga a coleção pessoal desta arquiteta que dedicou parte de sua vida a preservar a arte popular brasileira.

Prosseguindo até o bairro da Boa Viagem, na região central, a visita ao Museu de Arte Contemporânea de Niterói (MAC), projetado pelo arquiteto Oscar Niemeyer, fez-se obrigatória. O museu é o cartão-postal e símbolo do município. $O$ prédio é em si mesmo uma obra de arte e foi concebido para que o visitante desfrutasse de uma comunhão íntima com a beleza da visão da Baía de Guanabara interligando Niterói e Rio de Janeiro.

Subir a rampa que dá acesso às exposições permanentes e temporárias constituiu rara experiência de fruição, preparando-nos para conhecer diferentes sensações provocadas pelo que há de melhor na arte contemporânea brasileira e internacional. Ao adentrar o prédio, deixamo-nos afetar pelas características do espaço criado pela genialidade de Niemeyer, um misto de monumentalidade e simplicidade.

Beirando o litoral, indo em direção à Região Oceânica, seguimos para Itaipu. A vegetação do Parque Estadual da Serra da Tiririca nos surpreendeu pela exuberância. O Parque, a Praia de Itaipu, o Morro das Andorinhas e a Duna Grande formam um conjunto paisagístico de rara beleza. Chamou também nossa atenção uma comunidade indígena guarani que habitava o entorno. É nesse cenário que se localiza o Museu de Arqueologia de Itaipu. $\bigcirc$ prédio é bem simples e ainda tem o aspecto de ruína do antigo recolhimento de mulheres que lá funcionou. $\bigcirc$ museu, que pertence ao conjunto de museus do Instituto Brasileiro de Museus (lbram/MinC), é impecável em sua proposta de apresentar os vestígios arqueológicos do entorno, descobertas de sambaquis, referências de povos que lá viveram há milhares de anos, muito antes da chegada dos portugueses. 


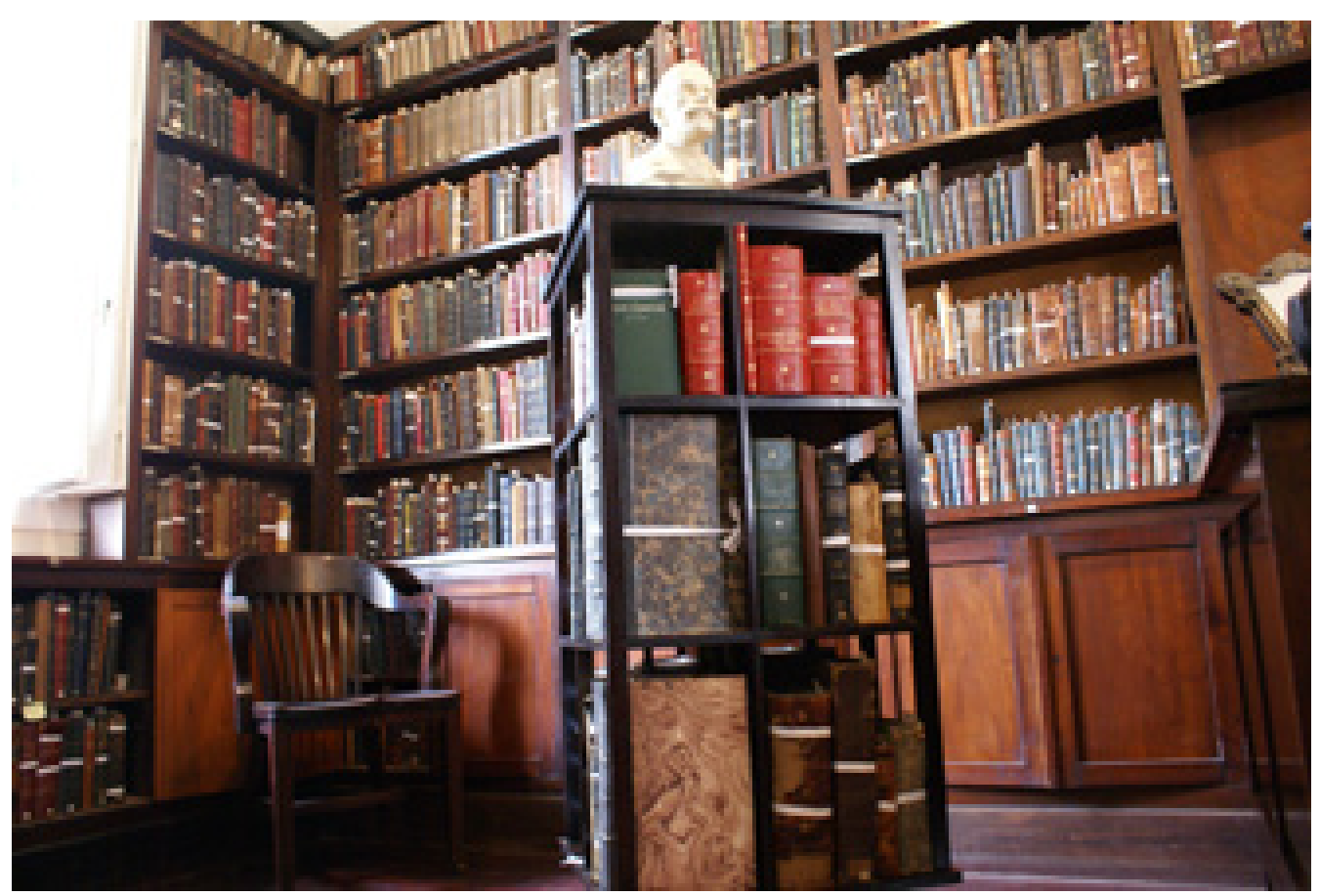

Casa de Oliveira Vianna - Niterói, RJ

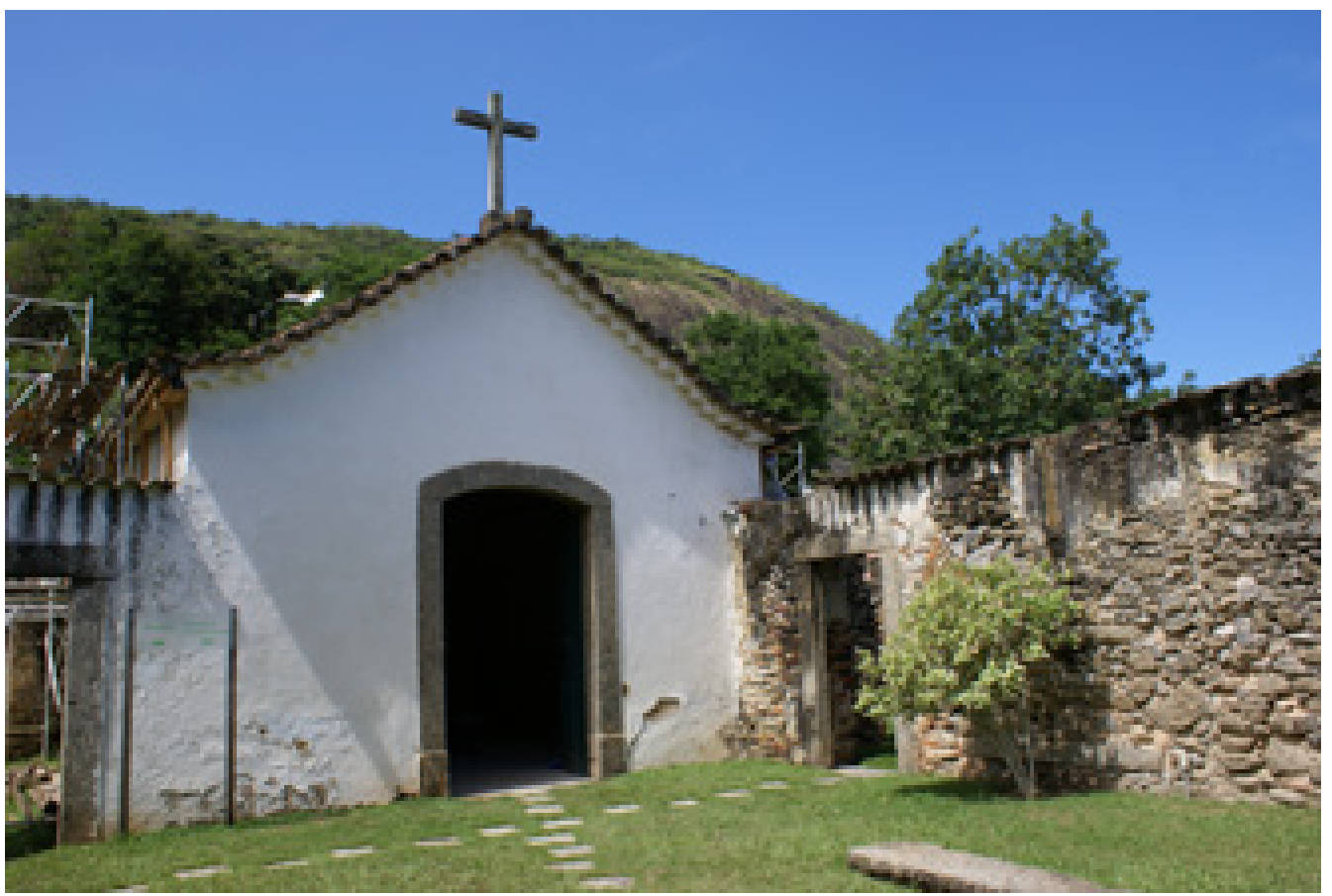

Museu de Arqueologia de Itaipu - Niterói, RJ 


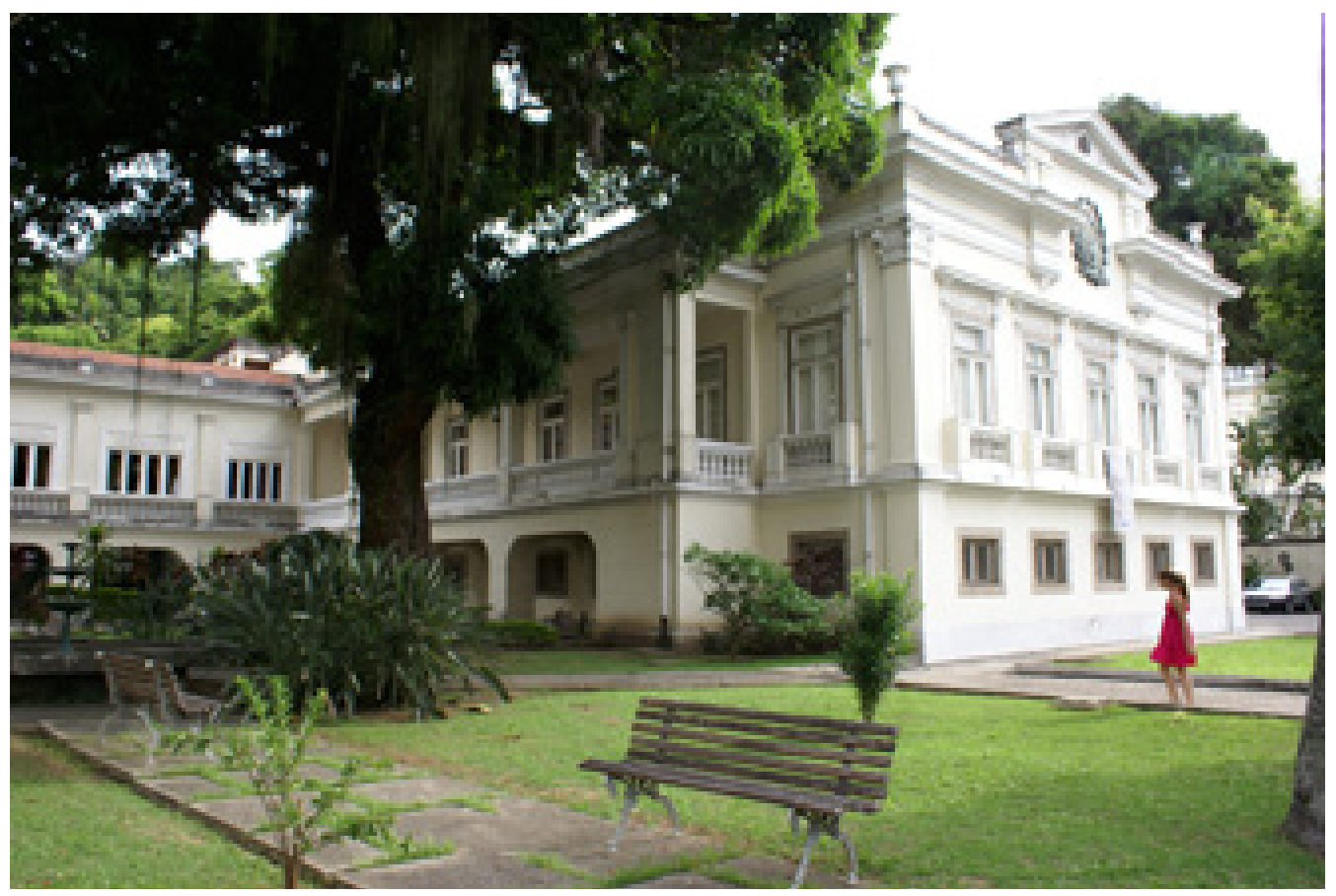

Museu do Ingá - Niterói, RJ

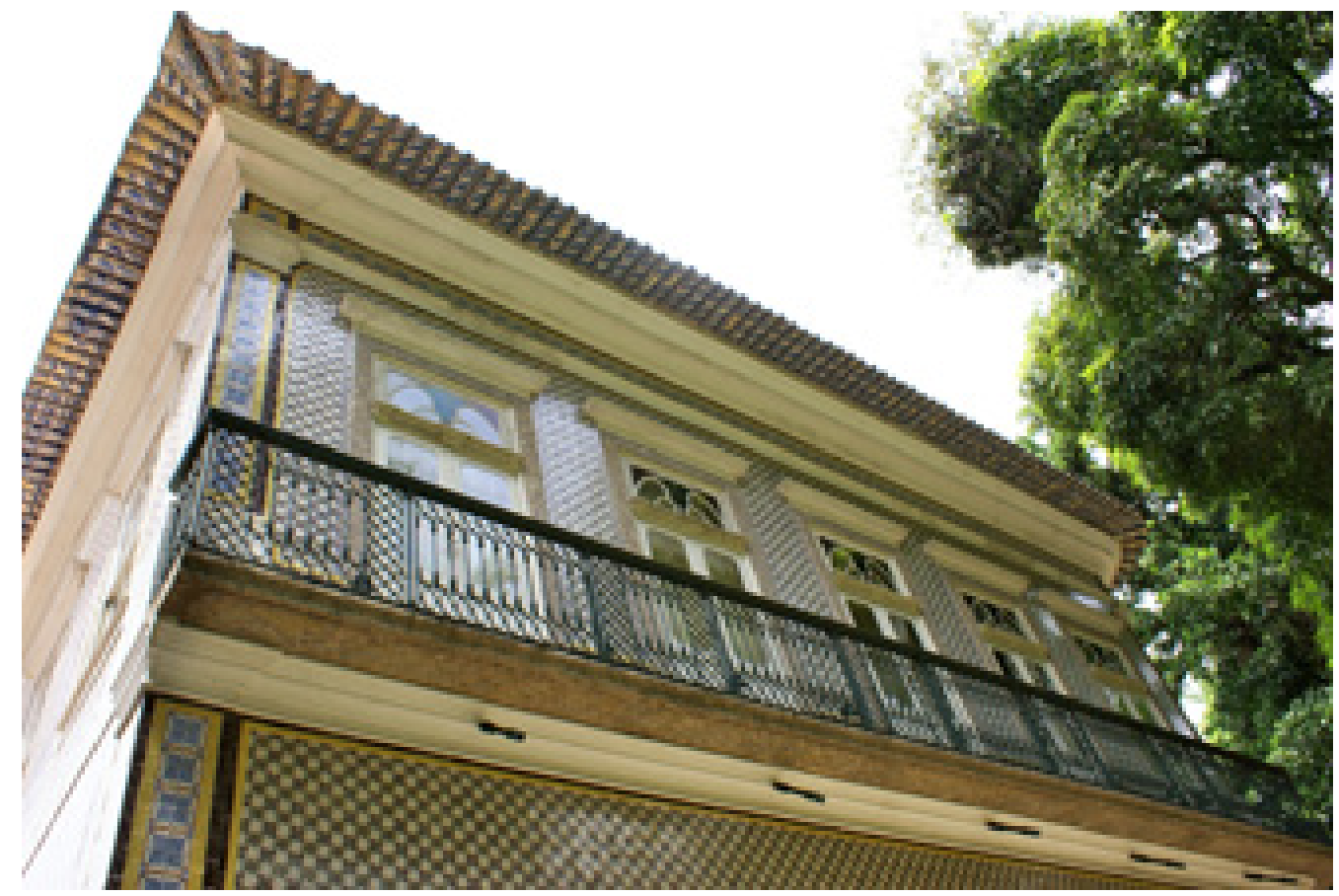

Solar do Jambeiro - Niterói, RJ 


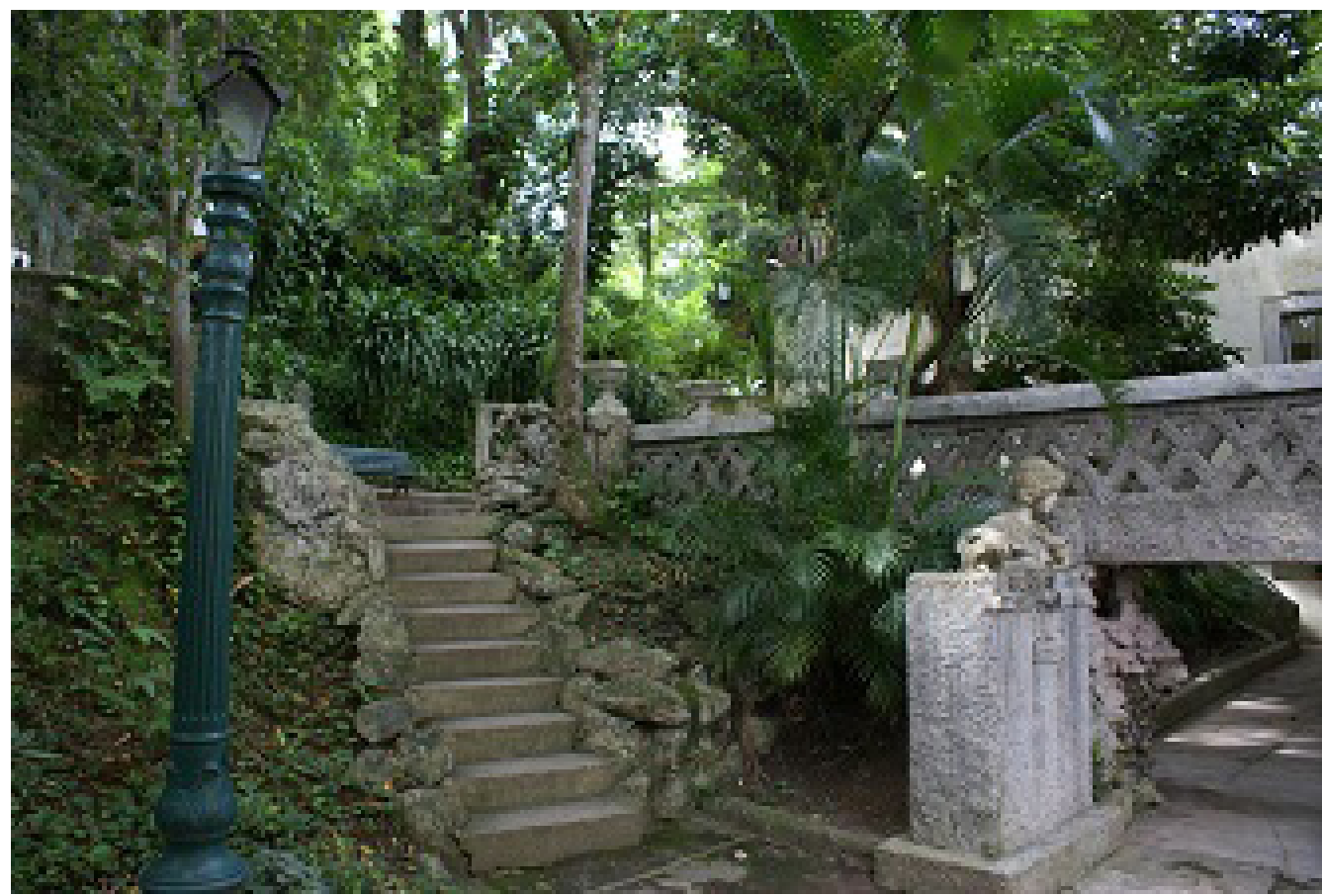

Museu Antônio Parreiras - Niterói, RJ

\section{Percurso 2- Município de Duque de Caxias:}

A partir do mapeamento de referências históricas no município, um grupo de professores, interessados na história da região, criou o Museu Vivo do São Bento, considerado um "museu de território", voltado para dar a conhecer o núcleo inicial de ocupação do atual município de Duque de Caxias.

O percurso tem início com as ruínas de uma antiga fazenda que pertenceu, no século XVI, à Ordem Beneditina, a Fazenda de São Bento, e que foi responsável pelo processo de colonização do Vale do Rio Iguaçu. Dessa fazenda, há ainda vestígios da casa grande, construída já no século XVIII.A capela, tombada pelo Instituto de Patrimônio Histórico e Artístico Nacional (Iphan), passava por processo de restauração na ocasião de nossa visita.

Ainda em Caixas, algumas experiências museológicas importantes chamaram nossa atenção, como o Museu Ciência e Vida, um projeto realizado e em plena expansão da Secretaria de Ciência e Tecnologia do Estado do Rio de Janeiro, por intermédio da Fundação Centro de Ciências e Educação Superior a Distância do Estado do Rio de Janeiro (Cecierj). O museu foi concebido para promover a aprendizagem pela experimentação e a interatividade, estimulando futuras vocações científicas. Tratava-se também do primeiro planetário digital da Baixada Fluminense, com cúpula fixa, com capacidade para 68 pessoas, onde 0 céu e todas as suas possibilidades podiam ser exploradas.

\section{Percurso Baixadas Litorâneas:}

Em tempos remotos, a região foi fartamente habitada por grupos indígenas, entre eles, os tamoios e os goitacases. Os primeiros fixaram-se na região onde hoje se situam Cabo Frio, Arraial do Cabo e Armação de Búzios. Já os 
goitacases ocupavam as terras ao norte, onde hoje encontra-se Rio das Ostras. Muitas outras etnias circulavam pela região, interagindo com uma natureza tropical especialmente pródiga em espécies animais e vegetais, sobretudo pescados e árvores frutíferas.

Há registros de desembarque de expedições europeias durante o século $\mathrm{XVI}$, entre as quais, a famosa expedição de Américo Vespúcio. Destacavam-se a facilidade de atracação dos barcos na Baía Formosa e a abundância de recursos naturais, como o pau-brasil. O potencial econômico e a presença do colonizador foram os principais motivos para o rápido desaparecimento da população indígena que ali vivia e que ou foi dizimada ou foi incorporada pela nova sociedade que ali se implantou.

Assim, alguns museus neste percurso destacaram-se por apresentarem alguns vestígios de formas muito diferentes de ocupação da terra e de modos de vida. Este foi o caso do Museu Arqueológico de Araruama, localizado na Rodovia I 24 que faz a ligação entre o Rio de Janeiro e diversas cidades da região. Nesse museu, as exposições demonstravam grande ecletismo. Numa parte, eram apresentados testemunhos da passagem dos povos indígenas naquele território. A partir de pesquisas do Departamento de Arqueologia do Museu Nacional, eram focalizados vestígios arqueológicos de três grupos: os povos sambaquieiros, os goitacases e os tupinambás. Já em outra parte da exposição, eram destacadas marcas da presença do colonizador europeu e dos povos africanos escravizados. O próprio prédio, construído por um comerciante português em 1862, abrigava a sede de uma fazenda cujo principal negócio girava em torno do tráfico de escravos, mesmo após a proibição do comércio internacional de escravos (1850). Casa grande e senzala estavam ali preservadas, evocando memórias subterrâneas de tempos pouco glamourosos.

Chegando a Cabo Frio, avistamos o Museu de Arte Religiosa Tradicional, notável testemunho das transformações pelas quais passou a região já sob a ocupação portuguesa. Localizado num antigo convento de frades franciscanos, o Convento de Nossa Senhora dos Anjos, cuja pedra basilar foi lançada em 1686 , a instituição dialoga fortemente com a cidade e seu entorno, sediando manifestações de artistas e produtores culturais e atuando em festas tradicionais, especialmente as de caráter religioso.

Em Arraial do Cabo, cidade vizinha a Cabo Frio, o Museu Oceanográfico do Instituto de Estudos do Mar Paulo Moreira é dedicado ao universo do oceano e seus múltiplos elementos. Um simulador de ondas reproduz o fenômeno de modo didático para o visitante.

Já ao norte da região, em Rio das Ostras, a descoberta de ossadas de indivíduos sambaquieiros, durante uma escavação, levou à criação do Museu de Arqueologia Sambaqui da Tarioba.Trata-se de um dos poucos museus de arqueologia in situ do Brasil, ou seja, onde o material é exposto da forma como foi encontrado. As ossadas eram de indivíduos de grupos sambaquieiros que ocuparam a região do litoral fluminense há mais de sete mil anos. Ou seja, esse museu apresenta instigante material de uma das mais remotas ocupações populacionais de que se tem notícia. O Museu de Arqueologia Sambaqui da Tarioba divide espaço com a Casa de Cultura Bento da Costa Júnior, local onde residiu uma família de riostrenses. Seus pertences estão ali expostos, tais como mobiliário, quadros, utensí- 
lios domésticos. Curiosamente, a edificação foi construída sobre os vestígios de um sambaqui que ali permaneceu encoberto por milhares de anos.

Embora pequenos, os museus encontrados neste percurso revelaram muitas memórias encobertas, hoje abertas para visitação e pesquisa. Valeu a pena se deixar levar.

\section{Percurso Norte-Fluminense:}

Partir em direção ao norte do Estado do Rio de Janeiro nos levou a um universo de contrastes profundos. Trata-se da região com maior PIB per capita do estado, em razão da exploração de petróleo na Bacia de Campos. Esse fenômeno muito particular vem contribuindo para transformar a feição da maior parte das cidades, não raro apagando vestígios de outros tempos. Museus e referências ao patrimônio histórico e cultural resguardam a memória da região, que está se transformando rapidamente.

Nesse cenário de importantes empreendimentos econômicos e urbanísticos, alavancados pela indústria petrolífera, a cidade de Campos dos Goytacazes vem confirmando o protagonismo na região. Protagonismo que atravessou diferentes períodos históricos, desde tempos remotos em que os jesuítas ali instalaram uma fazenda voltada para o aldeamento dos índios goitacases e para a produção econômica, visando à sustentabilidade da ordem religiosa. De lá para cá, a cidade viveu épocas sucessivas de empoderamento, das quais se destaca o período áureo do plantio e da comercialização da cana-de-açúcar, fonte de enriquecimento de grandes fazendeiros durante o século XIX. Os vestígios desses tempos ali estão em alguns casarios, em algumas fazendas e, sobretudo, nos museus.

O mais antigo é o Solar do Colégio, onde está sediado o Arquivo Público Municipal de Campos dos Goytacazes. O prédio constitui-se numa relíquia da maior relevância para os estudos históricos de uma dimensão nacional. O complexo arquitetônico foi construído entre 1650 e 1690 pelos irmãos da Companhia de Jesus do Rio de Janeiro, seguindo a planta de mesmo partido adotado em todos os colégios jesuítas: quatro alas, claustro assemelhado a um pátio interno e igreja. As paredes feitas de alvenaria de tijolo têm espessura de setenta centímetros. Os vãos de abertura apresentam moldura de pedra no térreo e madeira no segundo pavimento. $\mathrm{Na}$ fachada principal, destacada da sobriedade do conjunto, a capela com sobrevergas e porta almofadada. A torre do campanário tem a altura do frontão ondulado. $A$ medalha que aparece no frontão indica as datas de antigas reformas em 1803 e 1934. A finalização do telhado é em beira-seveira. Foi tombado pelo Instituto do Patrimônio Histórico e Artístico Nacional (Iphan) em 1946. Em 1977, foi desapropriado pelo governo do estado. Depois de longo abandono, o processo de restauração de seu conjunto teve início em 1995. Um projeto elaborado pela Universidade Estadual do Norte Fluminense Darcy Ribeiro (Uenf) viabilizou a cessão do prédio ao município para a instalação do arquivo público. Hoje, o antigo Solar do Colégio está vinculado à Fundação Cultural Jornalista Oswaldo Lima, órgão da prefeitura municipal de Campos dos Goytacazes, tendo sido inaugurado em 2002. Com séculos de história, o prédio impacta o visitante e estimulou nossa imaginação sobre suas diferentes ocupações e relevantes missões. Atualmente, guarda importante acervo arquivístico para a pesquisa, do século $\mathrm{XVI}$ aos nossos dias, 
inclusive documentos de escravos, entre os quais, ação de liberdade, devolução de escravo, furto, óbito, nascimento, impostos, escritura e testamento.

Destacaram-se ainda o Museu Histórico de Campos e o Museu Olavo Cardoso. O primeiro, instalado num prédio histórico, o Solar do Visconde de Araruama, apresentava a trajetória da cidade em exposições permanentes e temporárias. $O$ segundo era um museu-casa, onde conhecemos um pouco dos hábitos e costumes das elites campistas da primeira metade do século $X X$. Instalado na antiga residência de Olavo Cardoso, proeminente usineiro e filantropo campista, o museu expõe um acervo de mobiliário, louças, quadros e vestimentas. A casa, com 12 cômodos, é uma construção do fim do século XIX com face para a rua, porão e jardins. $O$ salão principal serve de antessala para os quartos e a sala de jantar.Além de focalizar a memória de seu patrono, o museu certamente contribui para preservar e divulgar a memória da própria cidade de Campos dos Goytacazes.

Já em Quissamã, fomos surpreendidos por um conjunto patrimonial peculiar. As antigas residências dos fazendeiros de açúcar foram restauradas e um trabalho de educação patrimonial e formação de guias abriu-nos a perspectiva de conhecer um pouco mais sobre a memória e a história locais.

Seguimos para o Museu Casa Quissamã, instalado na antiga sede da Fazenda de Quissamã, símbolo nobiliário da região e residência de um dos mais influentes homens de seu tempo, José Carneiro da Silva, Barão e Visconde com Honras de Grandeza de Araruama. Centro produtor, base econômica e política da capital do Império, a Casa Quissamã integra um dos registros iconográficos mais importantes sobre o século XIX: o livro Brazil pittoresco, primeira obra de viajantes publicada na América Latina, em 186I. As litografias que a compõem foram feitas a partir de fotografias tiradas porVictor Frond, hóspede em Quissamã, com texto de Charles Ribeyrolles.

Da varanda, situada no corpo central da casa, observamos extasiados a aleia de palmeiras imperiais e um centenário baobá, árvore sagrada para antigos escravos vindos da África e que ali está graças à diligência de um escravo que trouxe de além-mar uma semente para seu plantio em terras brasileiras.

Assim como diversas outras propriedades imponentes construídas no século XIX na região, e que foram adquiridas com suas terras pela Cia. Engenho Central de Quissamã, o que restou do solar ficou abandonado durante várias décadas. Recentemente, a propriedade foi adquirida pela prefeitura municipal de Quissamã, restaurada e transformada no Museu Casa Quissamã, futura sede do Parque Municipal que utilizará o trecho local do canal Campos-Macaé como área de lazer.

Ainda em Quissamã, o Complexo Cultural da Fazenda Machadinha é um dos pontos altos de um percurso de visitação a museus e referências patrimoniais nessa região. A Fazenda Machadinha, bem tombado desde 1979, é formada pela casa grande, hoje em ruínas, por antigas senzalas preservadas pelos próprios moradores - descendentes dos escravos que ali permaneceram após a abolição -, pela antiga cavalariça e pela capela de Nossa Senhora do Patrocínio.

Em 200I, a prefeitura de Quissamã desapropriou todo esse conjunto, restaurou as antigas senzalas, criou o Memorial sobre a origem dos negros de Quissamã e a Casa das Artes, ligada ao projeto Raízes do Sabor, e a manifestação de danças como o fado, o jongo e o boi malhadinho, típicas da época da escravidão. 
Em 2009, famílias remanescentes dos antigos escravos, que ainda viviam na Machadinha, tiveram reconhecida a propriedade definitiva das terras e dos imóveis, sendo oficialmente reconhecidos como uma comunidade quilombola. Esse reconhecimento deveu-se ao fato de o conceito de quilombo ter sido revisto nas últimas décadas, abrangendo grupos que desenvolveram práticas cotidianas de resistência na manutenção e reprodução de seus modos de vida. Esse é o caso dessa comunidade que manteve modo de vida próprio, possuindo laços familiares entre si. Todos descendem de apenas duas famílias que nasceram ali, e os que saíram em busca de trabalho e moradia em outro local continuaram mantendo contato com a região e seu estilo de vida.

Em nosso percurso, fomos surpreendidos com o Solar dos Mellos - Museu da Cidade de Macaé. $O$ próprio prédio, um singelo chalé de fundo romântico, construído em I89I, reforça o contraste com o panorama atual da cidade. Obra do mestre português Manuel Ribeiro Capellão, do carpinteiro Affonso de Souza e do pintor Alfredo de Almeida, foi construído a mando do coronel Bento de Araújo Pinheiro, sediando, mais tarde, a residência da família Mello.Vinculado à Fundação Macaé de Cultura, o Solar também abriga a sede da Subsecretaria de Acervo e Patrimônio Histórico (Semaph) e o Centro de Memória Antonio Alvarez Parada. Em seus jardins, é possível assistir a filmes e participar de eventos culturais, como o Café Literário, no qual cronistas da cidade compartilham com o público lembranças de uma Macaé que não existe mais.

Partindo em direção ao Noroeste Fluminense, destaca-se o Museu e Casa de Cultura de Aperibé.A instituição está instalada numa antiga estação de trem, construída em 1896, preservando também uma antiga e representativa edificação da cidade. Guardião da memória e da identidade aperibense, esse "espaço de memórias" permite que o visitante conheça antigas formas de morar e de conviver na região por meio de objetos que foram doados pelos próprios moradores da cidade e que estão impregnados por marcas pessoais e coletivas. Para o pesquisador da memória e da história fluminense, a instituição constitui um "achado" repleto de fontes e de referências.

Ainda na Região Noroeste, no município de Bom Jesus do Itabapoana, encontramos o Espaço Cultural Luciano Bastos, inaugurado em agosto de $20 \mathrm{II}$. Trata-se de uma iniciativa familiar para preservar, na sede do Colégio mais tradicional da cidade, não só a trajetória dessa importante instituição, mas também a história do município.

Muito ainda há por fazer com relação à dinamização e à construção de equipamentos culturais e museus numa região com tantos vestígios relevantes de memória para o estado do Rio de Janeiro e mesmo para o país. Os museus existentes nos chamam particularmente a atenção por constituírem empreendimentos da vontade de memória dos representantes da sociedade civil ou da administração pública. Torcemos para que iniciativas como essas proliferem. 


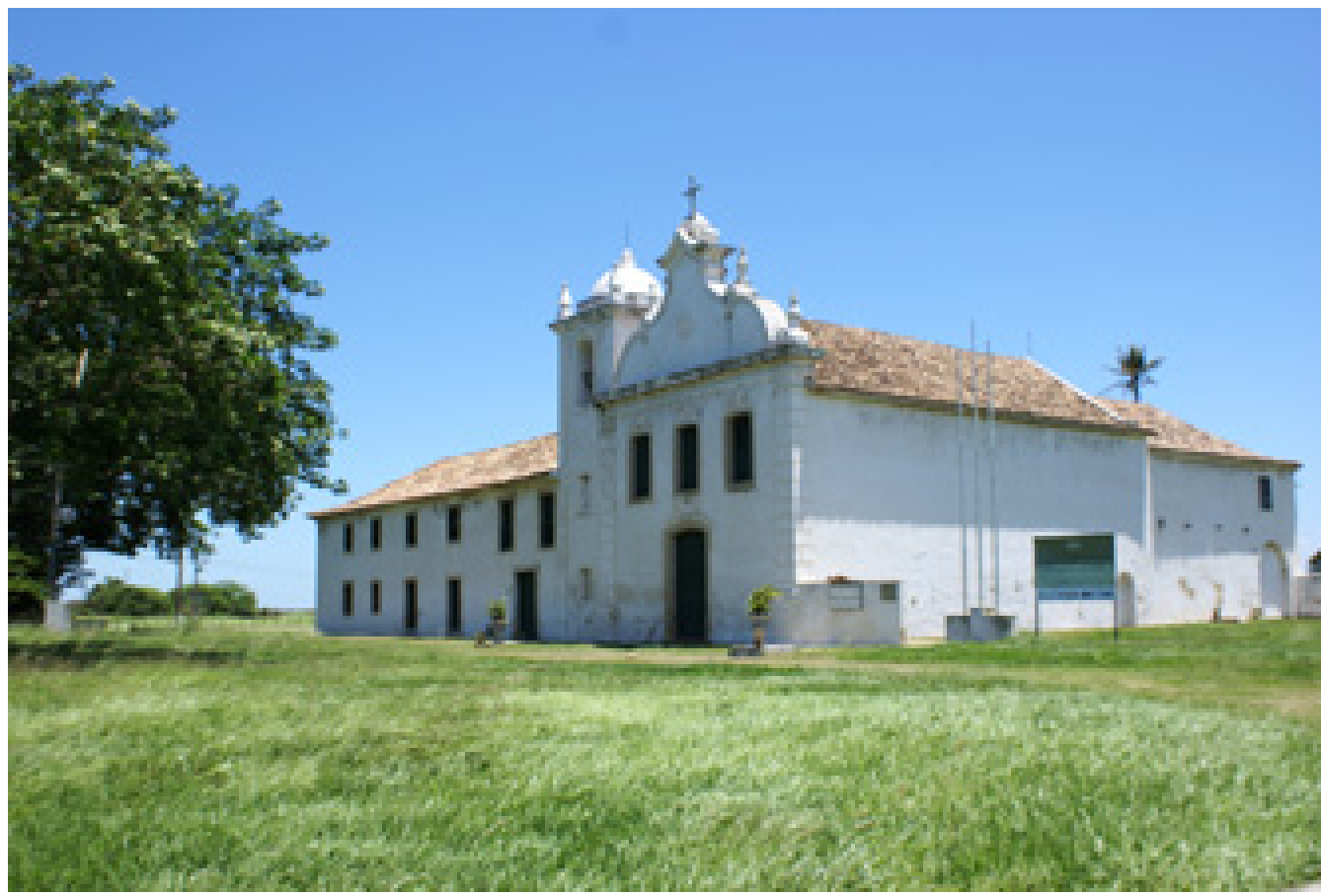

Solar do Colégio - Arquivo Público Municipal - Campos dos Goytacazes, RJ

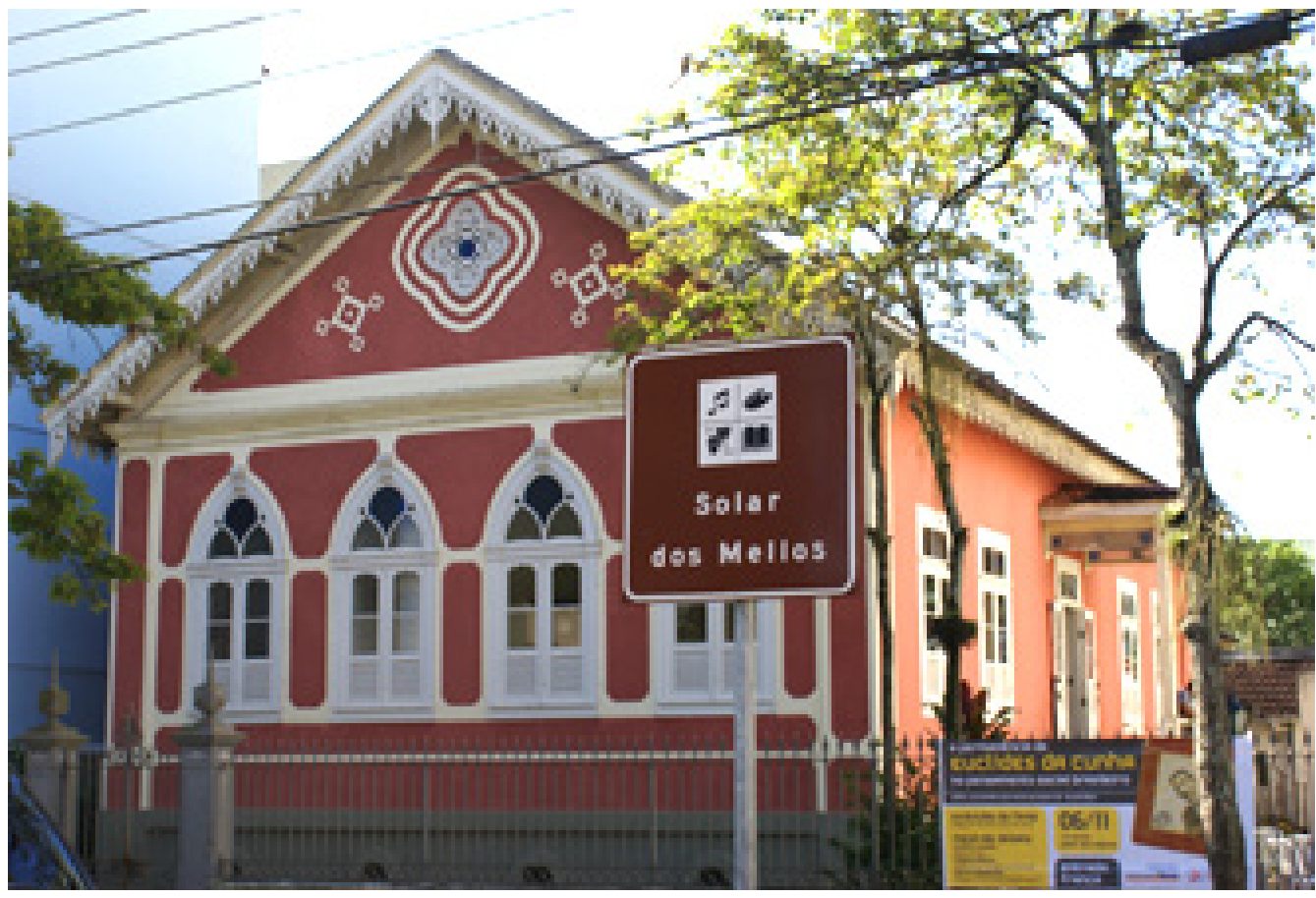

Solar dos Mellos - Museu da Cidade de Macaé - Macaé, RJ 


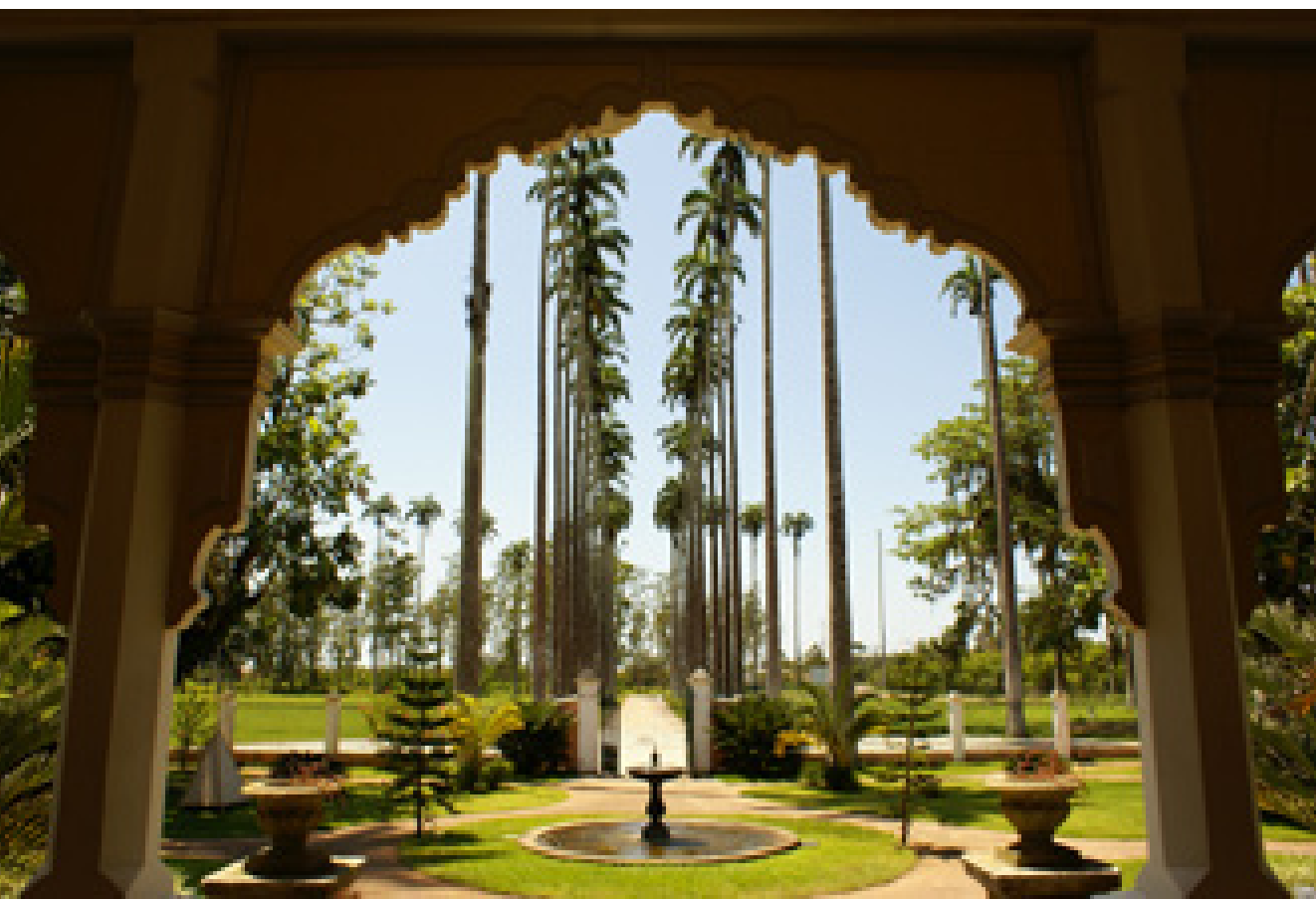

Museu Casa Quissamã - Quissamã, RJ

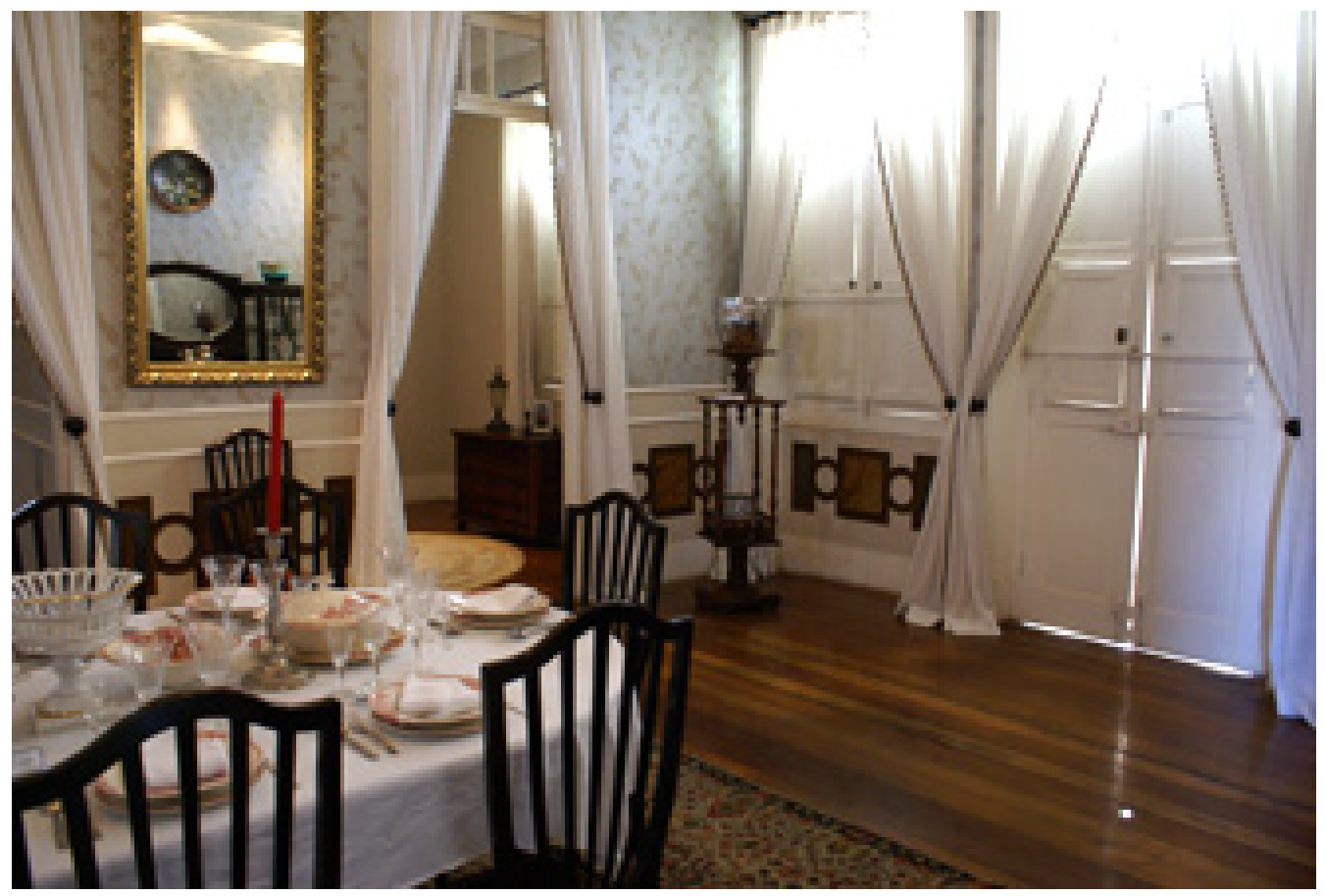

Museu Olavo Cardoso - Campos dos Goytacazes, RJ 


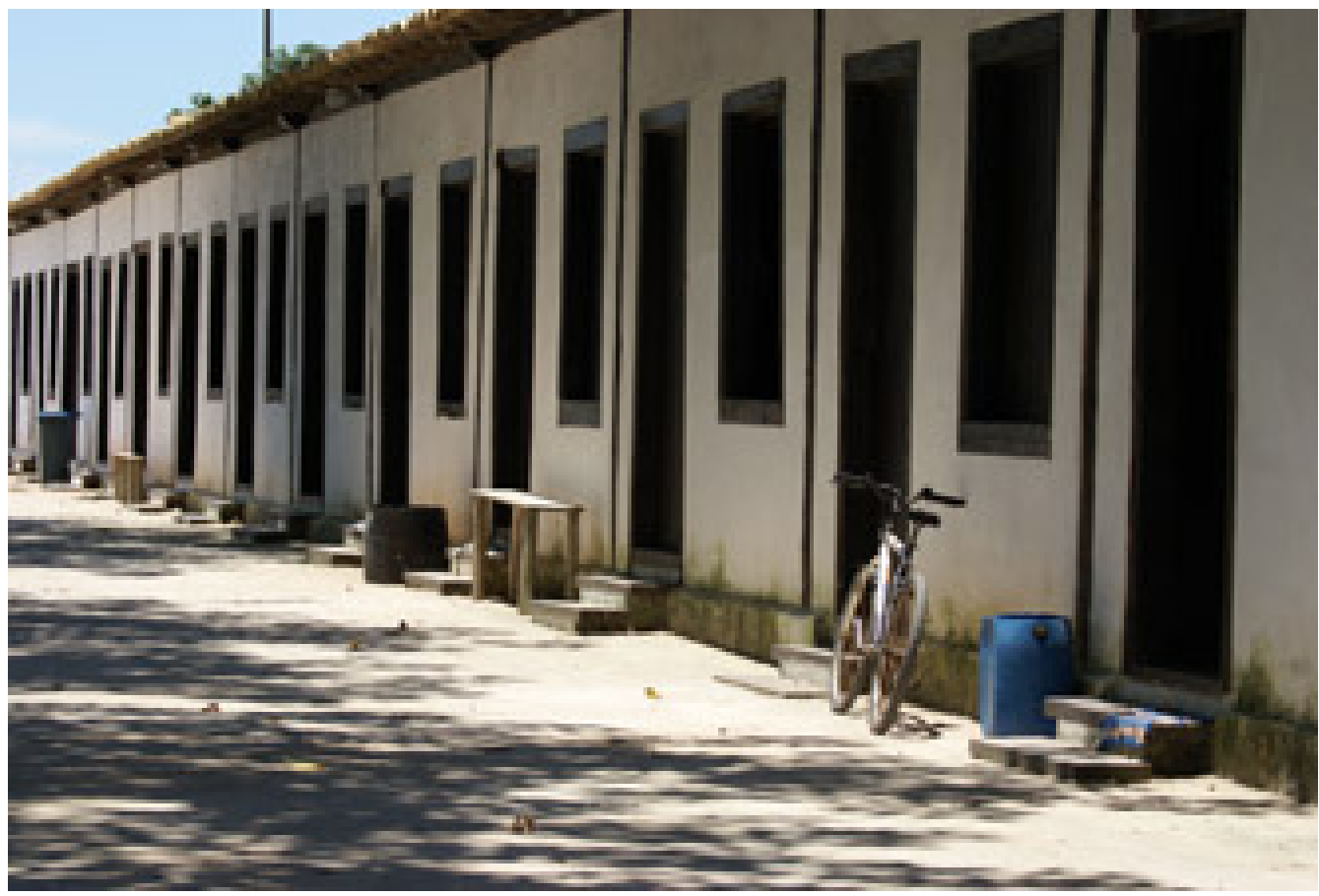

Complexo Cultural Fazenda Machadinha - Quissamã, RJ

\section{À guisa de (in) conclusão:}

O projeto "Museus do Rio" é um projeto "em processo" permanente de pesquisa e atualização. $O$ formato do portal, concebido para difundir parte de seus resultados, é muito útil neste sentido.A facilidade de fazer alterações, ampliar a pesquisa e os comentários, permite que a cada ano, novas descobertas possam ser agregadas. Desse modo, ainda haveria muito a comentar, o que se torna inexequível no curto espaço deste artigo. Certamente, as entrevistas com as narrativas recolhidas formam um capítulo instigante da pesquisa. Para nossos leitores, é possível acessar por intermédio do portal <www.museusdorio.com. br> os vídeos com as filmagens editadas, onde nossos interlocutores podem ser ouvidos e vistos, bem como os membros da nossa equipe.As novas tecnologias digitais, bem empregadas, têm sido pois de grande utilidade para a pesquisa.

Para finalizar, optamos pois por deixar aqui algumas das reflexões que a pesquisa nos instigou e que seguem nos alimentando em nossos cursos e seminários. Encontramos lado a lado grandes e pequenos museus, museus das elites e museus populares, museus centrados em personagens históricos, e também museus que se formaram pela nostalgia de mundos que desapareceram como os museus ferroviários, espalhados por todo o estado e que tão bem expressam a saudade dos antigos ferroviários que viviam do trem e para o trem. Há vestígios muito antigos como os solares de Campos e Macaé que testemunharam os primeiros aldeamentos indígenas, as missões jesuíticas, os ciclos econômicos da cana de açúcar, da transformação da cultura canavieira para a cultura cafeeira e depois para pastos de gado e que agora observam atônitos a transformação da região pela força do petróleo e do pré-sal. São prédios imponentes que abrigaram originalmente corporações de jesuítas que ali fizeram as primeiras fábricas 
e empresas lucrativas do país. Mas, há também museus que são coleções de toda uma vida como o museu de conchas de Mangaratiba, resultado do esforço de um colecionador que conta a história das transformações do local por meio das conchas que foram desaparecendo e que ali jazem testemunhas de épocas de bio-diversidades mais pulsantes num local hoje repleto de habitações precárias, lajes, puxadinhos, prédios de pequenos apartamentos lançando-se em penhascos que se projetam para o mar. Ou ainda o museu do surf em Cabo Frio, resultado de uma coleção de um surfista entusiasmado com o esporte que é capaz de narrar por meio de seus preciosos objetos minúcias da história internacional do surf: a primeira prancha enorme de madeira, miniaturas de surfistas famosos, fotos antológicas, prêmios recebidos por destemidos desafiadores de ondas no Hawaí... Ou ainda o museu da cachaça, resultado da coleção de um antigo aviador apaixonado por rótulos de garrafa de cachaça que disponibilizou "a coleção de uma vida inteira" para visitação pública na pequena cidade de Paty do Alferes no centro sul fluminense, iniciativa que vem contribuindo para a dinamização do turismo na região.

Eles estão por toda a parte, espalhados pelo estado, sintoma de uma vitalidade enorme que abre um leque de inúmeras possibilidades de histórias e memórias. De espaços consagrados aos grandes heróis da história pátria a espaços de valorização de pequenos heróis das mais ínfimas localidades, os museus constituem hoje espaços cada vez mais relevantes respondendo ao nosso anseio por referências, elos, conexões com diferentes temporalidades. Como assinalou Andreas Huyssen, os museus nos seduzem e num certo sentido nos confortam. Aliviam o mal estar que parece fluir de uma sobrecarga informacional e percepcional combinada com uma aceleração cultural, com as quais nem a nossa psique nem os nossos sentidos estão bem equipados para lidar. Quanto mais rápido somos empurrados para o futuro global que não nos inspira confiança, mais forte é o nosso desejo de ir mais devagar e mais nos voltarmos para a memória em busca de conforto."'3 Mas, que conforto podemos esperar da memória e dos museus se hoje as grandes narrativas se perderam, se não há senão sentidos breves, fugazes, permanentemente construídos e negociados? Onde estão as memórias coletivas que se afirmavam em mitos e ritos? Onde estão os coletivos produtores de memórias persistentes? O que são os museus na contemporaneidade senão fragmentos cujos sentidos não escapam ao paradigma contemporâneo da fugacidade, da mudança, da velocidade? Mesmo estas instituições feitas para durar expressam cada vez mais dinâmicas de grande mobilidade.

A metodologia da "etnografia audiovisual de percursos" vem nos sinalizando para múltiplas possibilidades de leitura de rotas e paisagens onde os museus do estado do Rio de Janeiro configuram-se em sinais de tempos e espaços variados. Se um prédio é conservado, se um acervo é preservado, se um museu é edificado e se isto faz parte de uma política cultural num município, podemos ler este fato como significativo. Guardamos aquilo que faz sentido para nós e descartamos aquilo que não nos serve ou não queremos lembrar.A memória não se faz espontaneamente, ela necessita de agentes e suportes, e os museus podem ser lidos como estes elementos que sinalizam algo sobre aqueles que os constróem e os mantém. E também sobre os que os modificam ou os renegam e destroem.

Assim, os museus que habitam o estado do Rio de Janeiro emergiram 
para nós como seres vivos, pulsantes, expressivos, que contam histórias sobre espaços-tempos, e que despertaram em nós, pesquisadores-flaneurs do século $X X I$, certo sentido de alteridade absolutamente necessário para novos sentimentos e percepções das paisagens. É preciso experimentar o recurso flaneur na pesquisa, aceitando o convite deWalter Benjamin. Percorrer cada cidade e de uma cidade a outra deixando-se levar pela satisfação de encontrar aberta uma porta de museu e simplesmente entrar. Solicitar a alguém que ali está que nos conte sua história e a história daquele museu.Abrir os sentidos para narradores experientes no sentido que Benjamin atribui para a categoria "experiência": alguém que tem uma história pra contar porque inicia seu relato a partir da sua vivência, da sua relação íntima com o prédio, com os objetos, com a instituição.

Os sentimentos diante destes seres museais são diversos. Também porque são polifônicos estes lugares de memória. Assim como as lembranças. Fazer a etnografia dos percursos em museus tem possibilitado que ecoem múltiplas vozes. Os museus são espaços com muitas camadas estratigráficas, que não raro são contraditórias. No caminho da cidade do Rio de Janeiro para a cidade de Araruama na Costa do Sol, um museu apresentava à primeira vista a memória de uma fazenda de café com vestígios do que outrora foi uma casa grande. $\mathrm{Na}$ parte de trás, havia alguns fragmentos do que teria sido uma senzala. Mas, a grande surpresa foi encontrar neste mesmo espaço ossadas e conchas encontradas numa escavação, deixando visível a memória dos sambaquieiros, povos antigos que viveram no Brasil antes dos tupi. A memória é assim. Não tem fim. Por debaixo de uma camada tem outra e outra e outra e mais outra. Memórias que nem sempre se encontram ou se combinam. Memórias que por vezes se contrastam, se enfrentam, se contradizem. $O$ território das memórias não é um território apaziguado, pelo contrário, constitui um campo de disputas e tensões. Não é tudo que fica. O campo das memórias pode ser descrito como um campo de forças, onde algumas se agenciam e outras se contrapõem.

E seguindo nosso percurso sobre os museus do estado do Rio de Janeiro, encontramos também memórias que operam como contra-memórias. Museus que longe de narrar histórias glamourosas, valorizam o esforço de populações pobres em construir suas trajetórias. Museus construídos em comunidades carentes, como o Museu Vivo do São Bento, empreendido com baixíssimo recurso, muita simplicidade, mas como muita eficácia em sua "vontade museal" de dar corpo a memórias nunca antes relatadas. Ficamos com a impressão de que experiências como esta vêm trazendo formas de empoderamento social e de uma nova apropriação dos sentidos do espaço, transformando territórios lisos em paisagens rugosas, iluminando o que antes era opaco e invisível. Assim, a pesquisa em curso vem nos ensinando não apenas a ler os museus, mas lê-los em relação com o entorno, o contexto, as memórias, as narrativas. O Museu Vivo do São Bento é um bom exemplo. Seria mais um museu na paisagem do estado do Rio de Janeiro, não fosse o fato de estar localizado numa das localidade mais estigmatizadas da região e surgir juntamente com uma atitude proativa de transformação social, política e, sobretudo, da forma como particularmente tem sido visto o município de Duque de Caxias. Conhecido no imaginário do carioca e do fluminense como local de grupos de extermínio, milícias, aliado ao fato de abrigar o maior lixão da região - o aterro de Gramacho - e ainda uma refinaria de petróleo, onde tudo contribui para a degradação da qualidade de 
vida dos moradores. Os moradores destas paragens áridas da região metropolitana do Rio de Janeiro frequentemente internalizam um sentimento de baixa auto-estima associando-se a um lugar periférico e relacionando-se de forma negativa com o espaço onde vivem. Suas aspirações incluem a busca por uma porta de saída deste lugar e o acesso a outros espaços valorizados socialmente. É neste contexto que a iniciativa de alguns indivíduos, militantes da memória e do patrimônio locais, me parece significativa. Ao procurar recuperar ainda que idealmente uma história local, onde um passado mais digno é acionado, este grupo articula-se num esforço de re-existência, alterando a rota de um destino aparentemente letal. Os sujeitos desta nova narrativa de esperança para o bairro de São Bento em Duque de Caxias são professores do ensino médio, a maior parte de História. Estas iniciativas de patrimonialização e musealização inscrevem-se em novas construções de percepções espaciais e de ressignificações de paisagens visando a dignidade social num espaço socialmente degradado.

A “etnografia audiovisual dos percursos" no estado do Rio de Janeiro tem nos conduzido a mundos jamais imaginados, mundos que se situam na fronteira entre temporalidades muito distintas que ao se mesclarem ressignificam as experiências de vida e as percepções da paisagem. Nossos narradores ou guias de museus são intermediários em nossos objetivos de restaurar elos perdidos, vínculos que se romperam entre as muitas histórias que se superpuseram no contexto do Rio de Janeiro. Alguns, como os narradores do Museu Vivo do São Bento são agentes do que Andreas Huyssen chama de rememoração produtiva, que podemos também denominar de rememoração propositiva, onde escrevendo a história de um modo novo os agentes sociais possam garantir um futuro de memória. $O$ museu vivo do São Bento associa-se claramente à expansão e ao fortalecimento de esferas públicas da sociedade civil,onde me parece crucial esta ocupação da cidade pelos seus mais diversos cidadãos. É exatamente por meio de uma proposta de novas percepções de paisagens já tão sucateadas que se torna possível acalentar um fio de esperança no porvir. E este fio de esperança ancora-se na alteridade produzida por imagens esquecidas de um passado pleno de dignidade. $E$ isto se dá justamente porque este passado antes de se fundar na nostalgia, pelo contrario, anuncia a potência de novos agenciamentos.

\section{Referências:}

ABREU, Regina . "Colecionando museus como ruínas: percursos e experiências de memórias no contexto de ações patrimoniais." In: Ilha. Revista de Antropologia (Florianópolis), v. I, p. I7-37, 2012. In: <www.reginaabreu.com>

ALBERTI,Verena, Tratamento das Entrevistas de História Oral no CPDOC, in: Centro de Pesquisa e Documentação de História Contemporânea do Brasil-CPDOC / FGV -www.cpdoc.fgv.br I < http://cpdoc.fgv.br/producao_intelectual/arq/I 505. pdf> acessado em: 9/2/2015

CHAGAS, Mario. A imaginação museal: museu, memória e poder em Gustavo Barroso, Gilberto Freyre e Darcy Ribeiro. Rio de Janeiro: Ibram/Garamond, 2009.

GUIA DOS MUSEUS BRASILEIROS, IBRAM, MINC in: http://www.museusdorio. com.br/joomla/images/stories/guia/Guia_dos_Museus_Brasileiros_Regiao_Sudeste.pdf (acessado em 13/02/2015) 
DELEUZE, Gilles e GUATTARI, Felix, Introdução: rizoma. In: Mil Platôs: capitalismo e esquizofrenia.Volume I. Rio de Janeiro: Editora 34, 1995.

DEVOS, Rafael. "Quando a câmera vira "personagem": ponto de vista em movimento na busca de imagens do outro em documentários etnográficos", in: Revista lluminuras, vol. 2, n. 3, UFRGS, 200I <http://seer.ufrgs.br/index.php/iluminuras/ article/view/9||7>.

ECKERT, Cornelia, "Apresentação", In: Revista lluminuras, v. I3, n. 32 (20I3).

GEERTZ, Clifford. A Interpretação das Culturas, RJ, Zahar Editores, 1978.

HALBWACHS, Maurice. Memória coletiva. São Paulo: Centauro, 2004.

HUYSSEN, Andreas. Seduzidos pela memória, RJ, Ed.Aeroplano, 2000, pág. 33

MIZOGUCHI, Danichi Hausen. Segmentaricidades: passagens do Leme ao Pontal, SP, Ed. Pleiade, 2009, pág. 84.

NORA, Pierre. Entre memória e história: a problemática dos lugares. Projeto História, Revista do programa de estudos pós-graduados em História e do Departamento de História. São Paulo, n. 10, p. I-78, dez., 1993.

RIBEIRO, José da Silva. Antropologia Visual, Práticas Antigas e Novas Perspectivas de Investigação, Rev. Antropologia, vol 48, n. 2, SP, Jul/Dez 2005< http://www. scielo.br/scielo.php?pid=s0034770 $2005000200007 \&$ script $=$ sci_arttext $>$ acessado em: 9/2/20I5.

ROCHA, Ana Luiza Carvalho e ECKERT, Cornelia "Imagem recolocada: pensar a imagem como instrumento de pesquisa e análise do pensamento coletivo". In: Revista lluminuras v. 2, n.3; Publicação Eletrônica do Banco de Imagens e Efeitos Visuais - NUPECS/LAS/PPGAS/IFCH e ILEA/UFRGS, 200 I 